\title{
Small mammals (Chiroptera, Didelphimorphia, and Rodentia) from Jaíba, middle Rio São Francisco, northern Minas Gerais State, Brazil
}

\author{
Marcelo Rodrigues Nogueira ${ }^{1,5}$, André Pol ${ }^{2}$, Leila Maria Pessôa ${ }^{3}$, João Alves de Oliveira ${ }^{4}$ \& \\ Adriano Lúcio Peracchi ${ }^{2}$ \\ ${ }^{1}$ Universidade Estadual do Norte Fluminense, Laboratório de Ciências Ambientais, Campos dos \\ Goytacazes, RJ, Brazil. \\ ${ }^{2}$ Universidade Federal Rural do Rio de Janeiro, Laboratório de Mastozoologia, Seropédica, RJ, Brazil. \\ ${ }^{3}$ Universidade Federal do Rio de Janeiro, Departamento de Zoologia, Rio de Janeiro, RJ, Brazil. \\ ${ }^{4}$ Universidade Federal do Rio de Janeiro, Museu Nacional, Setor de Mamíferos, Rio de Janeiro, RJ, Brazil. \\ ${ }^{5}$ Corresponding author: Marcelo Rodrigues Nogueira,e-mail: nogueiramr@gmail.com
}

NOGUEIRA, M.R., POL, A., PESSÔA, L.M., OLIVEIRA, J.A., PERACCHI, A.L. Small mammals (Chiroptera, Didelphimorphia, and Rodentia) from Jaíba, middle Rio São Francisco, northern Minas Gerais State, Brazil. Biota Neotropica. 15(2): e20140126. http://dx.doi.org/10.1590/1676-06032015012614

\begin{abstract}
We report the results of small mammals inventories conducted in the region of Jaíba, northern Minas Gerais state, southeastern Brazil, from 1990 to 1995. This region is located in the southern limit of the Caatinga biome, and harbors a unique set of natural ecosystems and extensive agricultural areas. With a total effort of 2964 trap-nights and 44 net sessions, we captured 893 small mammals from 46 species, including four marsupials, 13 rodents, and 29 bats. We report on species that are endemic to the Caatinga (Wiedomys pyrrhorhinos and Xeronycteris vieirai), and species that are new to the mammal fauna of the state of Minas Gerais (Tonatia saurophila, X. vieirai, and Myotis lavali). We also provide the first valid voucher-supported record of Micronycteris sanborni from southeastern Brazil, and extend the known range of $X$. vieirai $800 \mathrm{~km}$ southward. All bats highlighted here as endemic or representing new records were associated to limestone outcrops, suggesting that preservation of this kind of habitat may be particularly relevant to the conservation of these mammals.
\end{abstract}

Keywords: Caatinga, limestone outcrop, endemic species, range extension, taxonomy.

NOGUEIRA, M.R., POL, A., PESSÔA, L.M., OLIVEIRA, J.A., PERACCHI, A.L. Pequenos mamíferos (Chiroptera, Didelphimorphia, and Rodentia) de Jaíba, médio Rio São Francisco, norte do estado de Minas Gerais, Brasil. Biota Neotropica. 15(2): e20140126. http://dx.doi.org/10.1590/167606032015012614

Resumo: Reportamos os resultados de inventários de pequenos mamíferos conduzidos na região de Jaíba, norte de Minas Gerais, sudeste do Brasil, entre 1990 e 1995. Essa região está localizada no limite sul do bioma Caatinga, e abriga um conjunto único de ecossistemas naturais e extensas áreas cultivadas. Com um esforço total de 2964 armadilhas-noite e 44 sessões de captura com redes de neblina, nós capturamos 893 pequenos mamíferos, que permitiram a identificação de 46 espécies, incluindo quatro marsupiais, 13 roedores e 29 morcegos. Nós reportamos espécies endêmicas da Caatinga (Wiedomys pyrrhorhinos e Xeronycteris vieirai) e espécies que são novas para a fauna de mamíferos de Minas Gerais (Tonatia saurophila, X. vieirai e Myotis lavali). Nós também fornecemos o primeiro registro válido, com material testemunho, de Micronycteris sanborni para o sudeste do Brasil, e estendemos a distribuição geográfica conhecida de $X$. vieirai em $800 \mathrm{~km}$ na direção sul. Todos os morcegos destacados aqui como endêmicos ou representando novos registros estiveram associados a afloramentos de calcário, sugerindo que a preservação deste tipo de hábitat pode ser particularmente relevante para conservação desses mamíferos.

Palavras-chave: Caatinga, afloramento de calcário, espécie endêmica, extensão de distribuição, taxonomia. 


\section{Introduction}

The region of Jaíba, in northern Minas Gerais state, has been classified under high levels of biological importance at both regional and national scales (Costa et al. 1998, MMA 2002). It is located in the southern limit of the Caatinga domain (Andrade-Lima 1981) and harbors a unique set of ecosystems, influenced by the proximity with the Cerrado biome and the presence of water courses, lagoons, and limestone outcrops. This region also holds one of the largest irrigation projects in South America (Projeto Jaíba) (Rodrigues 2001), which over the past decades has converted thousands of hectares of natural habitats into agricultural plots and anthropic areas.

Spix \& Martius (1828) provided the earliest records on the mammals of northern Minas Gerais state in their list for the "Sertão dos Campos Gerais de São Felipe". These authors reported two marsupials and 10 rodents, in addition to several medium to large mammals, but no precise locality records were provided. Hershkovitz (1987) described this list as an "uncritical compilation", including data from a variety of sources. Empirical, voucher-supported records were obtained, therefore, only in the 1990s, but these data remained under restricted access (available only as meeting abstracts) until Oliveira et al. (2003) summarized them in a check list. This list has been very useful in the evaluation of the biological importance of Jaíba, but lacks methodological and ecological information from the original surveys, including a list of the voucher material available. Part of the material collected in Jaíba during the 1990s was listed by Tavares et al. (2010) in a check list for the state of Minas Gerais, but more detailed information, including field observations, remain available only for a few taxa (Nogueira \& Pol 1998, Nogueira et al. 2003, 2008). In the most recent assessment of the bat diversity in northern Minas Gerais, Falcão et al. (2014) reported 22 species for the Mata Seca State Park, but no voucher material was prepared in this study. Herein we provide a revised list for the small mammals of Jaíba, including information on the sampling techniques, collection sites, taxonomy, and reproductive biology of selected species.

\section{Material and Methods}

\section{Sampling techniques and data analysis}

Terrestrial small mammals were captured using live traps

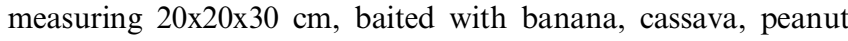
butter, codfish liver oil, and bologna. Traps were set in line transects, within which they were placed $10 \mathrm{~m}$ apart from each other, on the ground or in the lower strata of the dossel. We gave priority to places in which known or potential roosts (burrows, hollow trees, stones, ground vegetation), or water bodies, were available. The number of traps varied from place to place, but usually a total of 100 traps was used in each field trip. The number of traps used each day in each site was multiplied by the number of sampled days to estimate the capture effort, reported as the number of traps $\mathrm{x}$ nights (trap-nights).

Bats were sampled mainly at ground level with mist nets opened along trails inside or at the border of forests, close to flowering trees, water bodies, and roosts. In a few instances, hand nets were also employed inside roosts. Nets were usually opened just before dusk and closed between three to five hours later. Because no consistent information on the size and number of nets was recorded for each net session, we do not refer to any sampling effort based on these variables. Instead, we generally refer to "net sessions", which in most cases was equivalent to three $15 \mathrm{~m}^{2}$ nets opened along 4 hours. Excluding diurnal samplings at roost sites, a total of 44 net sessions were performed in Jaíba. Number of individuals captured in both mist nets and live traps were used to construct individual-based rarefaction curves (Magurran 2011). These analyses were performed in the software PAST version 2.17c (Hammer et al. 2001).

Together with captured specimens, we also considered in this inventory species represented by any sort of material evidence that could lead to an unequivocal taxonomic determination. Thus, carcasses, bone, and tegumental remains were collected and identified by comparison with specimens housed in the Mammals Collection at the Museu Nacional. Non-flying small mammals and a few bats were prepared as skin and skull, whereas most bats were prepared as fluidpreserved specimens. Voucher specimens were deposited at the Adriano Lucio Peracchi Mammal Collection, Laboratório de Mastozoologia, Instituto de Biologia, Universidade Federal Rural do Rio de Janeiro (ALP), and at the Mammals Collection at the Museu Nacional, Universidade Federal do Rio de Janeiro (MN). Select rodent species were also karyotyped following the protocol by Ford \& Hamerton (1956). Available karyotype data obtained from the specimens, as well as diagnostic characters relevant for identification, were included in the species accounts as "taxonomic notes" when regarded necessary. For rodents and marsupials, we report the weight and four standard external measurements, recorded in the flesh, respectively with a spring scale and a millimetric rule following Moojen (1943). Measurements of forearm and craniodental features of bats were taken with digital calipers following the protocol described by Williams et al. (1995). In the case of Micronycteris, we also measured the condyloincisive length from the anteriormost point of the upper inner incisors to the posteriormost point on the occipital condyles. Reproductive data, when available, is presented. Pregnancy and lactation were detected via palpation, and embryos were measured in natural position (crown-rump length).

Nomenclature and taxonomy adopted here for bats are the same used by Nogueira et al. (2014a). For rodents and marsupials we follow, respectively, Patton et al. (2015) and Gardner (2008).

\section{Study area}

The region of Jaíba is located in northern Minas Gerais state, between the right margin of the Rio São Francisco and the left margin of the Rio Verde Grande (Figure 1). Most specimens obtained in this region came from sites located around Mocambinho, a small village situated close to the right margin of the Rio São Francisco, in the municipality of Jaíba.

The Jaíba region is situated in the southern limit of the Caatinga, close to areas of Cerrado (Figure 1) (Andrade-Lima 1981, Fernandes \& Bezerra 1990, Rizzini 1997), and presents a number of distinct vegetation physiognomies, described in detail by Magalhães \& Ferreira (1976). The climate is mild semiarid, characterized by the occurrence of six dry months, from May to October (Nimer 1989). Mean annual rainfall and temperature were, respectively, $832 \mathrm{~mm}$ and $26.6^{\circ} \mathrm{C}$ (data from 1984 to 1994). For the same period, the month with the lowest mean rainfall was July $(1.7 \mathrm{~mm})$, whereas the highest mean rainfall was recorded in December $(236.9 \mathrm{~mm})$. July was also the 


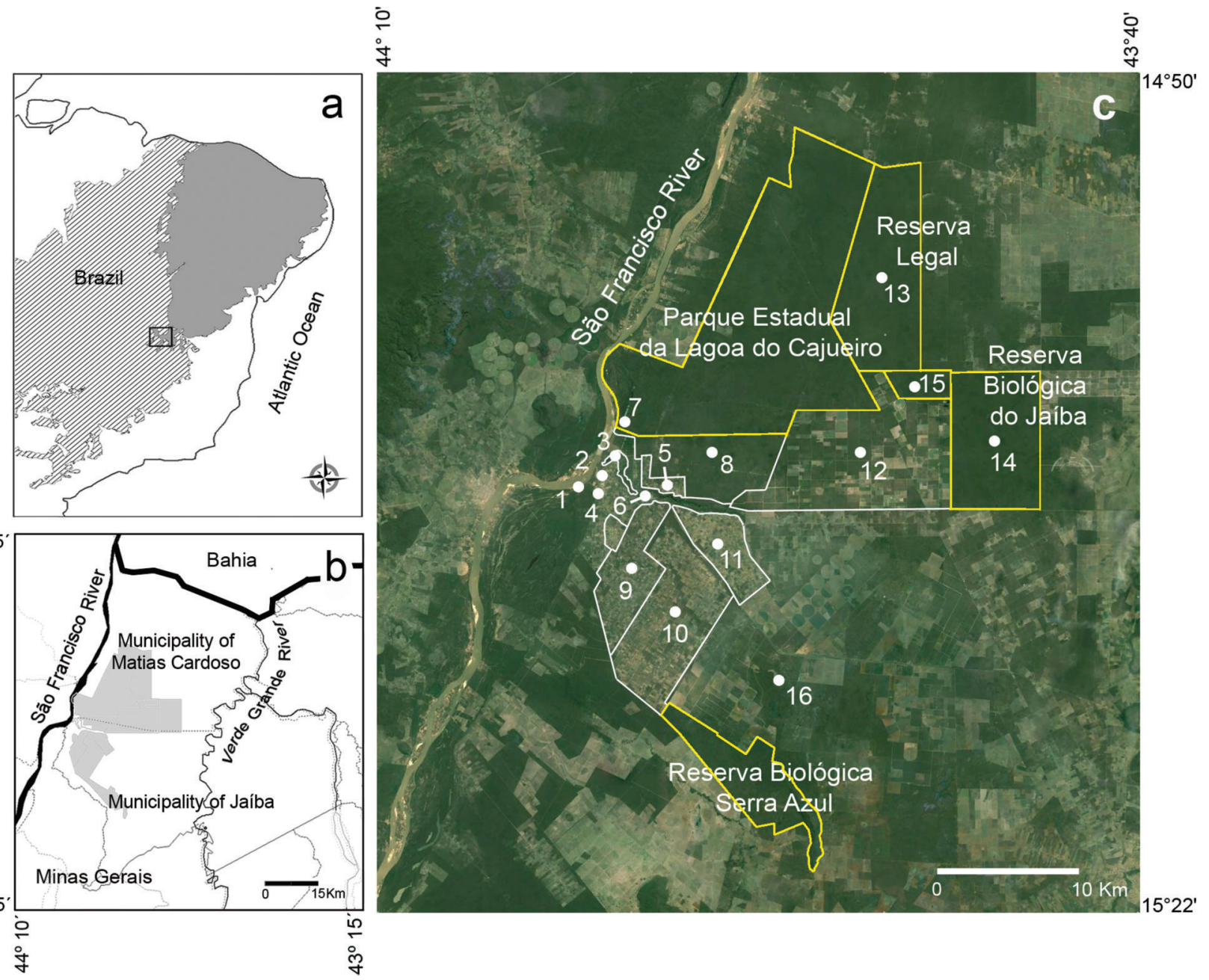

Figure 1. Maps showing the localization of the region of Jaíba at (a) the southern limit of the Caatinga biome (gray), close to areas of Cerrado (diagonal lines), and in (b) northern Minas Gerais state, southeastern Brazil (areas delimited in Figure 1c are represented in gray). Sites where small mammals were sampled at Jaíba are also shown, with delimitation of conservation units (yellow) and areas of the Jaíba Irrigation Project (white) where some of these sites are included (Rebio Serra Azul was not sampled, but site 16 represents the same habitat type: limestone outcrop) (c); see Material and methods for site names.

month with the lowest mean temperature $\left(24.5^{\circ} \mathrm{C}\right)$, while the highest mean $\left(28.4^{\circ} \mathrm{C}\right)$ was recorded in October. Most altitudes in the Jaíba region range from 440 to $500 \mathrm{~m}$, but the highest site of the region, at Serra Azul, achieves 724 m (Panoso et al. 1976).

Small mammals were sampled in the Jaíba region from March 1990 to July 1995, as part of the faunal monitoring program held by the Companhia do Desenvolvimento dos Vales do São Francisco e do Parnaíba (CODEVASF), in areas under influence of the Projeto Jaíba. Bellow we provide a brief description of the sampling sites (vegetation data mainly based on Magalhães \& Ferreira 1976) and information on the period of sampling and sampling effort. Labels used here include capital letters originally applied in the context of the Projeto Jaíba to areas that were subsequently converted into agricultural plots, and local names referring to geographical landmarks (rivers, lakes, mountains).

1. "Riacho Mocambinho" (1505'49" S, 4402'04" W): besides the Rio São Francisco and Rio Verde Grande, this is the only perennial water course in the region of Jaíba. Its riparian forest is recognized as an evergreen formation. Bat samples were obtained close to the confluence of the riacho Mocambinho and the Rio São Francisco. At this point, the riparian forest is reduced to a narrow stripe surrounded by várzea fields, an evergreen herbaceous-shrubby physiognomy, disturbed by anthropic influence. Capture effort: two net sessions (April 11 and October 24, 1994).

2. "Mocambinho" $\left(15^{\circ} 057^{\prime} 7^{\prime} \mathrm{S}, 44^{\circ} 01^{\prime} 08^{\prime} \mathrm{W}\right)$ : urban village located at the right margin of the Rio São Francisco, where roofs of residences were searched for the presence of bats. Capture effort: one net session on March 12, 1990; and two on October 6 and 21, 1994.

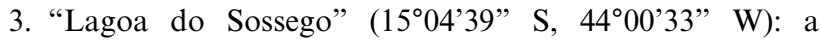
marginal lagoon of the Rio São Francisco. Terrestrial small mammal capture effort: 17 trap-nights on July 10 11, 1990; and 100 trap-nights on November 5-10, 1993. Bat capture effort: one net session on August 20, 1992.

4. "Campus Avançado de Monitoramento" (CAM) $\left(15^{\circ} 06^{\prime} 05^{\prime}\right.$ S, 4401'13" W): located close to the Rio São Francisco, this site is characterized by the presence of várzea fields and the anthropic fields. This latter formation is composed by shrubs, grasses, and sparse trees, including 
invasive and local species. We frequently observed Hymenaea and Calliandra (Leguminosae Fabaceae-Mimosoidea) at this site. Bat capture effort: seven net sessions (April 4-5, 17-18, 27, 30, 1994; and May 2, 1994).

5. "Reserva da Fazenda Yamada" ("Mata da Agroceres") $\left(15^{\circ} 04^{\prime} 18^{\prime} \mathrm{S}, 43^{\circ} 59^{\prime} 44^{\prime \prime} \mathrm{W}\right)$ : this area is adjacent to the Dreno Jaíba and is covered by a subcaducifolious forest, with a discontinuous upper stratum of canopy reaching $19 \mathrm{~m}$ in height. We also noticed the presence of Cereus jamacaru (Cactaceae), endemic to the Caatinga, at this site. Terrestrial small mammal capture effort: 126 trap-nights on March 10 12, 1990; 147 on July 7-11, 1990; 125 on August 18-22, 1990; 150 on June 23-25, 1992; and 90 on October 22-25, 1992. Bat capture effort: two net sessions on August 19 and 25, 1992, and one on October 10, 1994, in a trail inside the forest.

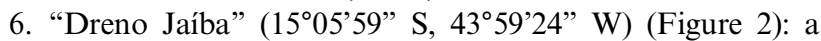
natural depression, also known as "Riacho Tapera", which is an extension of the "Lagoa do Sossego". Often flooded during the rainy season, as a result of the overflow of the Rio São Francisco and of the lagoon. The "Dreno Jaíba" is adjacent to the subcaducifolious forest of "Reserva da Fazenda Yamada". Terrestrial small mammals capture effort: 106 trap-nights on August 17-22, 1992. Bat capture effort: four net sessions close to the body of water (July 11, 1990; October 13 and 20, 1994; and February 21, 1995).

7. "Lagoa do Cajueiro" (1503'16" S, $44^{\circ} 00^{\prime} 19^{\prime}$ W): a lake complex that nowadays is part of a conservation area (Parque Estadual da Lagoa do Cajueiro). Terrestrial small mammals capture effort: 64 trap-nights set on June 24-25, 1992. Sixteen traps were set at the margin of one of the lakes, situated at Fazenda Profaz, eight at a dry forest situated between the lake and the Rio São Francisco, and eight in grasslands at the margin of this river, in the same area.

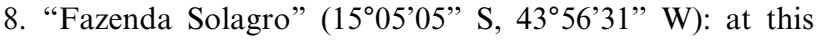
site bats were sampled in mist nets set at the border of a cattle pond (Figure 3). This pond was available even during the dry season. Vegetation around the pond was characterized as anthropic fields. Bat capture effort: two net sessions (November 14, 1994; January 13, 1995).

9/10. "Area B" $\left(15^{\circ} 10^{\prime} 41.72\right.$ "S, 435' 14.82 " W) and "Area A" $\left(15^{\circ} 8^{\prime} 39.25^{\prime \prime S}, 44^{\circ} 0^{\prime} 19.11^{\prime \prime} \mathrm{W}\right)$ : these sites were visited before their conversion into agricultural plots. Traps and nets were set in places dominated by homogeneous shrubby caatinga 2-3 m high. Terrestrial small mammals capture effort: 165 trap-nights on March 9-12, 1990; 256 trapnights on July 6-11, 1990; and 60 trap-nights on November 6-9, 1993. Bat capture effort: three net sessions on January 10-12, 1995.

11. "Area F" $\left(15^{\circ} 08^{\prime} 19^{\prime \prime S}, 43^{\circ} 56^{\prime} 10^{\prime \prime} \mathrm{W}\right)$ : at this area, the original cover of arboreal caatinga had been completely removed when traps were set. It was separated from the adjacent Area A, which was still bearing its forests at that moment, by an irrigation channel and a road. Samples were obtained in an agricultural plot mainly explored for banana plantations (Musa, Musaceae). A small orchard with fruiting trees, such as guavas (Psidium guayava,

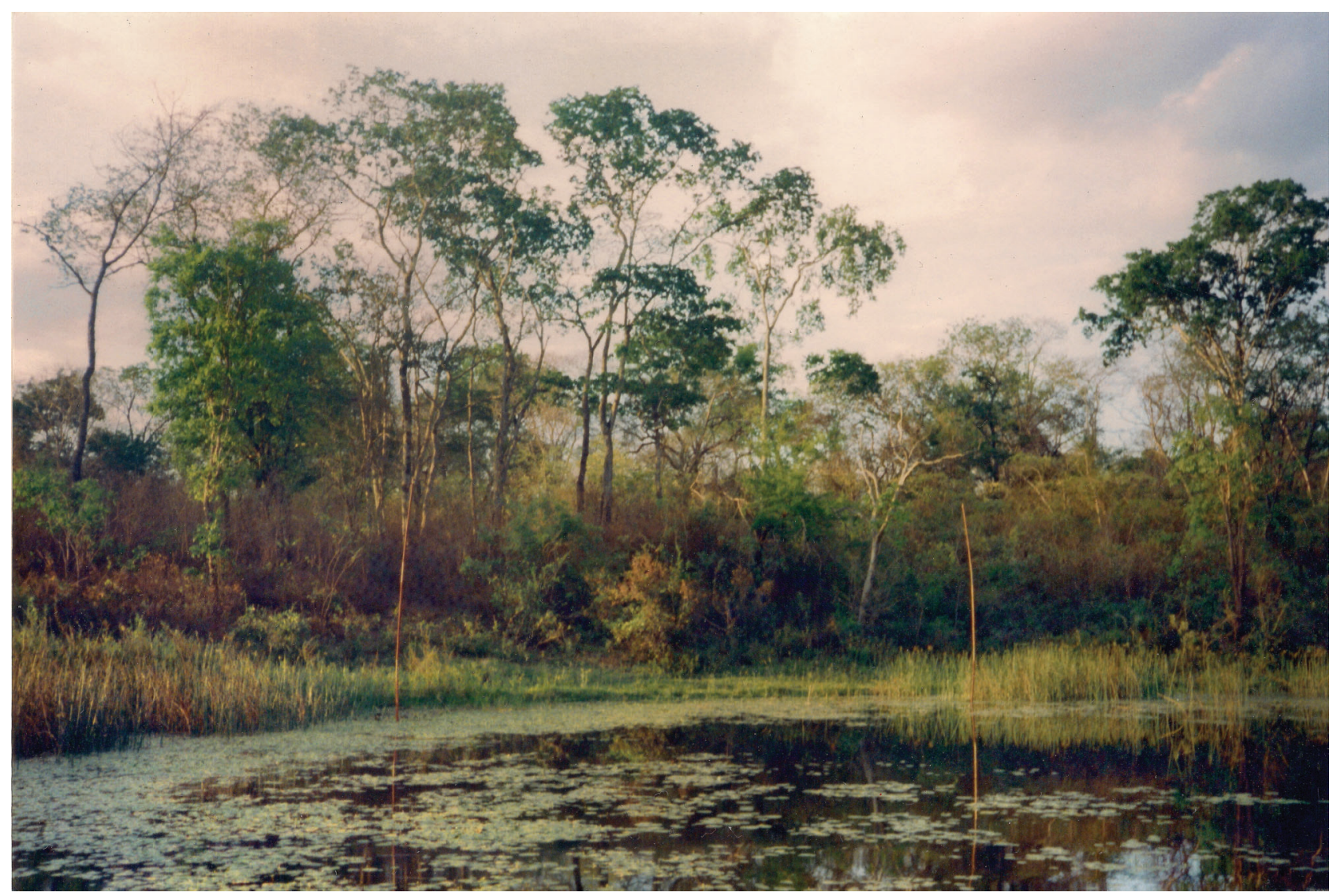

Figure 2. Dreno Jaíba, a natural depression at the right margin of the Rio São Francisco, region of Jaíba, northern Minas Gerais state. A subcaducifolious forest bordered the Dreno at this collecting site. 


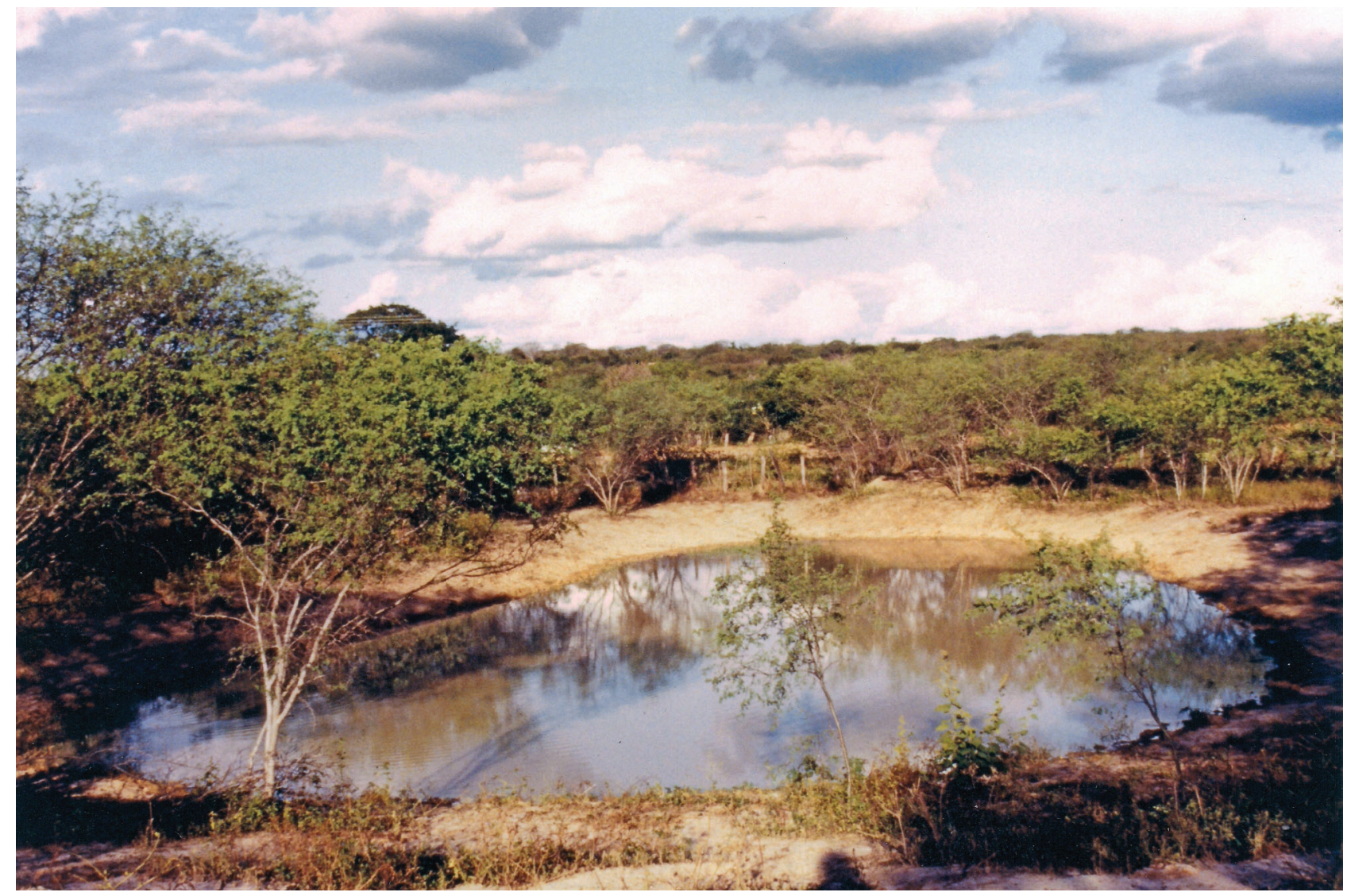

Figure 3. Cattle pond at Fazenda Solagro, region of Jaiba, northern Minas Gerais state. The surrounding area is characterized as anthropic fields.

Myrtaceae) and mangos (Mangifera indica, Anacardiaceae), was also present at this site. Terrestrial small mammals capture effort: 53 trap-nights on August 19-22, 1990. Bat capture effort: two net sessions (June 16, 1994; October 11, 1994).

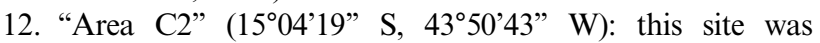
predominantly composed by arboreal caatinga, a deciduous formation in which the highest trees achieve 15 to $30 \mathrm{~m}$. Captures occurred during the clearing of the area to form agricultural plots, by sampling in recently disturbed forest edges. Terrestrial small mammals capture effort: 120 trapnights on August 18-22, 1990; 270 trap-nights on June 1922, 1992; 20 trap-nights on August 25-27, 1992; and 120 trap-nights between March, 30 and April, 2, 1994.

13. "Reserva Legal" (1457'52" S, 4350'3" W): a 20.281 ha area, originally designated to be a forest reserve, covered mainly by arboreal caatinga. Terrestrial small mammals capture effort: 50 trap-nights on September 25-28, 1990; 345 trap-nights on August 21-27, 1992, and 120 trapsnights between March 30 and April 2, 1994. Bat capture effort: two net sessions.

14. "Reserva Biológica do Jaíba" (Rebio Jaíba; $15^{\circ}$ $04^{\prime} 7.25^{\prime}$ 'S, 4345'37'W): a 6,358 ha area covered mainly by arboreal caatinga (Figure 4). Trees at this formation range from 6 to $12 \mathrm{~m}$ in height, and the shrubby strata included several lianas, cactus (e.g. Cereus), and bromeliads. It includes a marked anthropic area locally known as "Lagoa Santa", a water body already in accentuated drought in August, 1992, and with recorded presence of domestic animals. Terrestrial small mammals capture effort: 100 trap-nights on September 25-28, 1990; 15 on August 21, 1992; and 129 on November 6-9, 1993. Bat capture effort: two net sessions on August 21, 1992; and two on May 3 and 5, 1994.

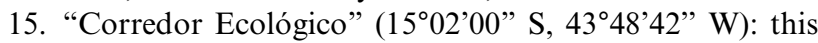
area connects the reserve areas "Reserva Legal" and "REBIO Jaíba", presenting the same type of vegetation (arboreal caatinga). As in the preceding site, traps were set in a trail perpendicular to the road that crosses the "Reserva Legal" and the "Corredor Ecológico". Terrestrial small mammals capture effort: 50 trap-nights between September 25-28, 1990.

16. "Fazenda Serra Azul": $18 \mathrm{~km}$ from the village of Mocambinho, in the road to Jaíba. The sampling area was a limestone outcrop locally known as "Morro Solto" (15¹3'14" S, 4354'06" W; ca. 510 m elevation). This serrote is covered by arboreal caatinga at its slopes and hyper-xerophytic at its top (Figure 5). This latter vegetation is characterized by the dominance of Cactaceae and bromeliads. Limestone cavities are abundant at Morro Solto, which is also characterized by the presence of some mesophytic plants such as Cecropia and Ficus. Terrestrial small mammals effort: 166 trap-nights on March 28-30, 1994. Traps were set in the limestone outcrop (46) and in the bordering dry forest (37). Bat effort: 11 net sessions (March 31, 1994; April 6-7, 9, 1994; June 14, 1994; August 26, 1994; October 14 and 25, 1994; February 20 and 28, 1995; and March 1, 1995) in the same habitats reported for terrestrial small mammals. 
Nogueira, M. R. et al.

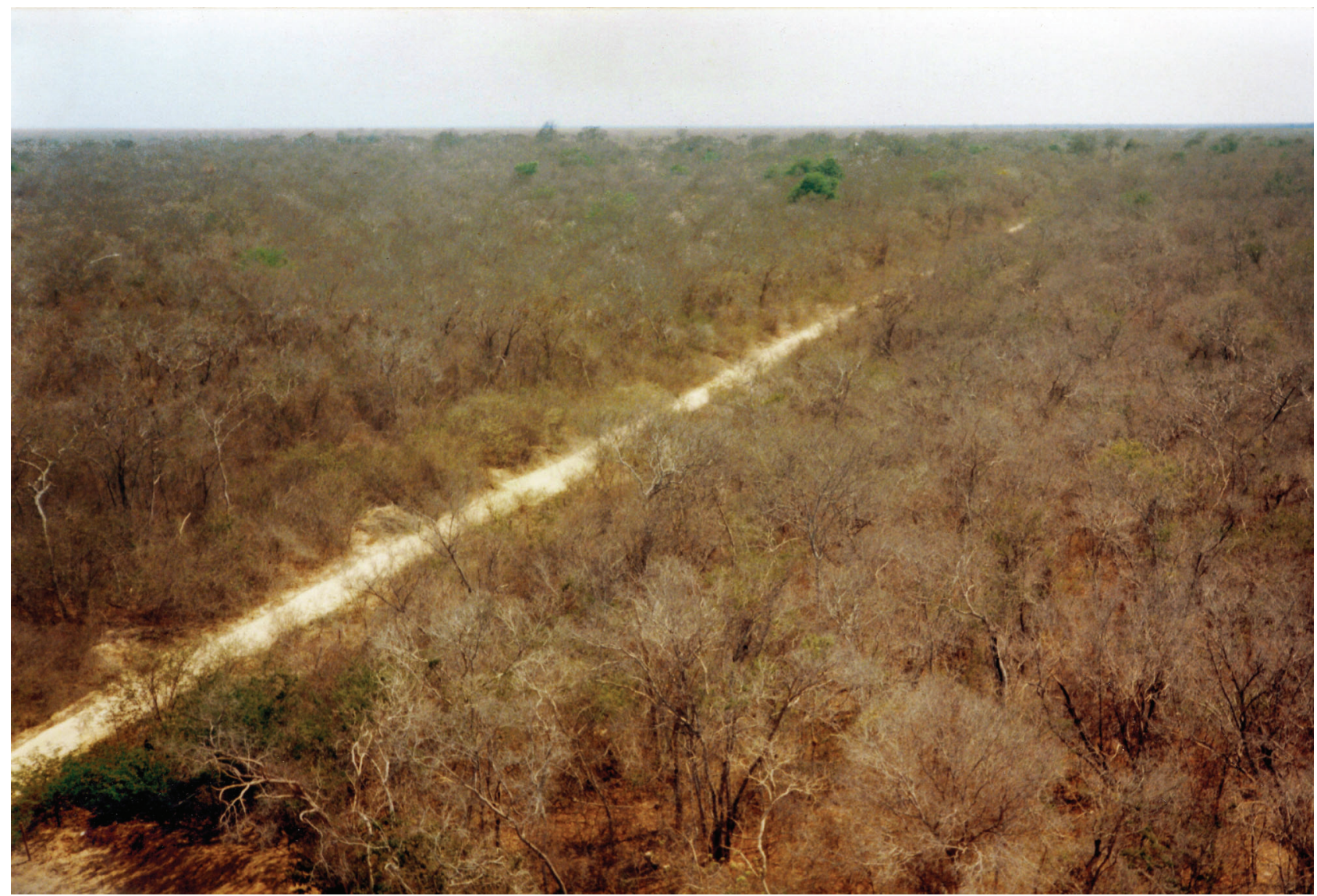

Figure 4. General view of the Reserva Biológica do Jaíba, region of Jaíba, northern Minas Gerais state, during the dry season. The typical vegetation here is the arboreal caatinga.

\section{Results}

With a total effort of 2964 trap-nights, 44 net sessions, and occasional samplings at roosts, we captured 893 small mammals, including 39 marsupials, 118 rodents, and 714 bats. A total of 403 specimens were prepared as vouchers, including 38 marsupials, 119 rodents, and 246 bats. Three additional rodents were recorded, one based on a manual capture and two based on material obtained from local hunters. The total numbers of species and genera for each of these orders are, respectively, 4/4, 13/13, and 29/23, for a total of 46 species, 40 genera, and 11 families. Species accumulation curves for both nonflying-small mammals and bats (Figures 6 and 7) show a tendency to stabilization, suggesting that most species prone to be captured by mist nets and live traps in the visited habitats were sampled.

The more common rodent species in our traps were Thrichomys apereoides (34\% among rodents only and $25 \%$ among non-flying small mammals) and Galea spixii (18\% and $13 \%$ for the same groups, respectively), while the more frequently captured marsupials were Marmosops incanus (49\% among marsupials only and 13\% among non-flying small mammals) and Monodelphis domestica (31\% and $8 \%$ for the same groups, respectively). Among bats captured in mist nets (individuals captured directly from roosts excluded), Desmodus rotundus was the most common species $(16 \%)$, which is related to our sampling at Morro Solto, where we found a large colony (ca. 150 individuals) in a cave. The second most common bat in mist nets was Artibeus planirostris (12\%), a species found to be widespread in the region, as were three other bat species, similarly common in our sample (Glossophaga soricina [10\%], Phyllostomus discolor $[10 \%]$, and Carollia perspicillata [9\%]). Together, these five species accounted for $50 \%$ of our captures in mist nets, while the other $50 \%$ was included in captures from 21 species. This abundance pattern, with few common species and a larger number of rare ones (Figure 8), was also observed in our data from live traps (Figure 9). Details of our captures at Jaíba are presented in the following account (measurements from voucher specimens in Tables 1 and 2).

Species accounts

Order Didelphimorphia

Family Didelphidae Gray, 1821

Didelphis albiventris Lund, 1840

Voucher material (4): males - MN 34403, 34438, 43812; female - MN 34390.

FIELD NOTES: the white-eared opossum was recorded in distinct habitats at the region of Jaíba, including the subcaducifolious forest at the Mata da Agroceres, the shrubby caatinga at the Area B, and the arboreal caatinga at the Rebio Jaíba. Juvenile specimens were recorded in February.

Gracilinanus agilis (Burmeister, 1854)

Voucher material (4): males - MN 29043, 34392, 34399; female - MN 34393.

FIELD NOTES: captured at Dreno Jaíba and at the Rebio Jaíba. 


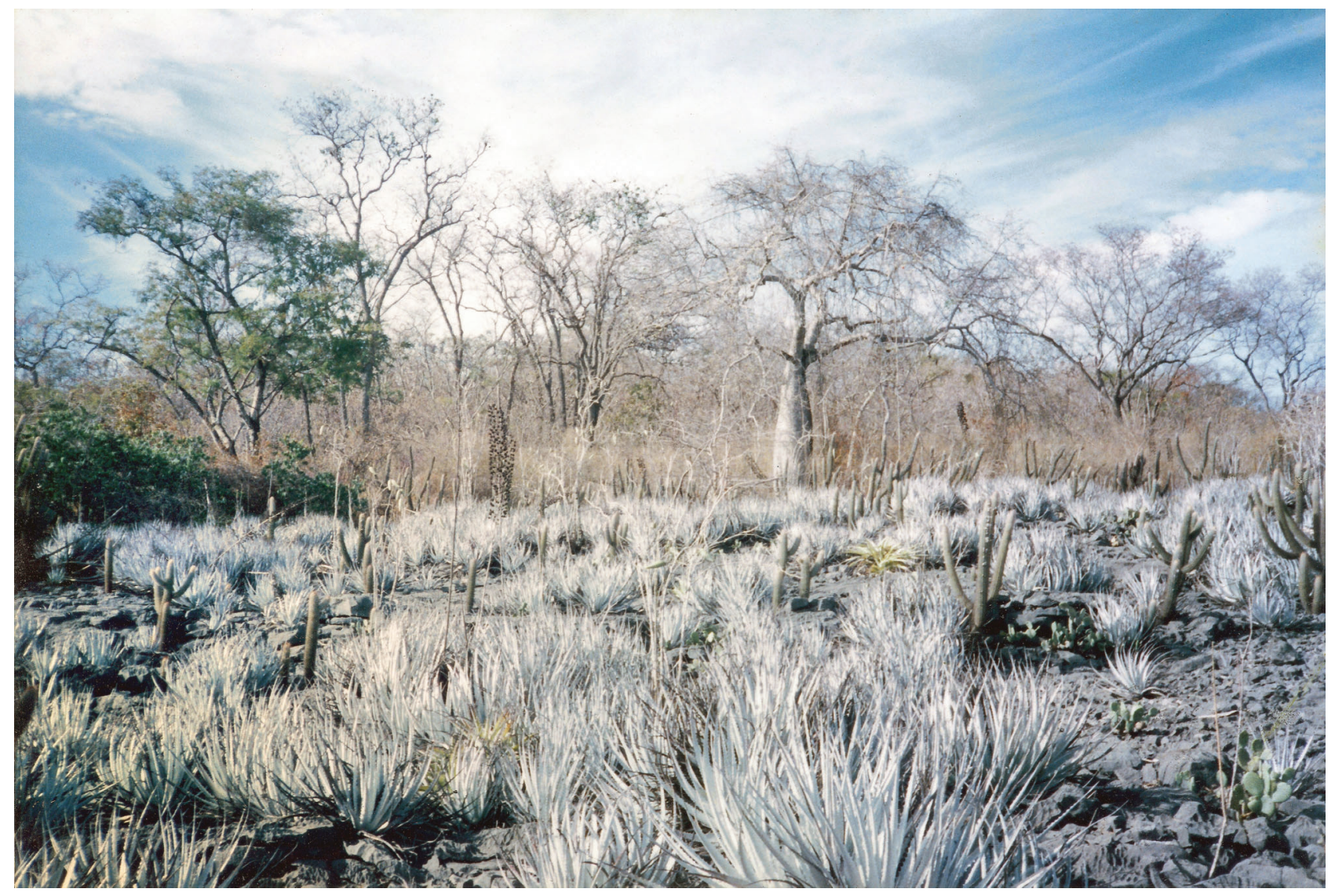

Figure 5. Limestone outcrop of Morro Solto, Fazenda Serra Azul, region of Jaíba, northern Minas Gerais state, with a view of the hyper-xerophytic caatinga (front) and the arboreal caatinga (back).

Marmosops incanus (Lund, 1841)

Voucher material (22): males - MN 28875, 28876, 28888, 29006, 29063, 33839, 33841, 34391, 34395, 34396, 34397, 34401, 34402, 34428, 46598, 81179; females - MN 28887, 29024, 29431, 34398, 46600, 46601.
FIELD NOTES: individuals were captured at Areas A and B, Mata da Agroceres, Rebio Jaíba, and Reserva Legal. Young specimens were obtained in March. Specimens obtained during this study were kept in captivity and analyzed in studies of age structure and reproduction in this species by Oliveira et al. (1992) and

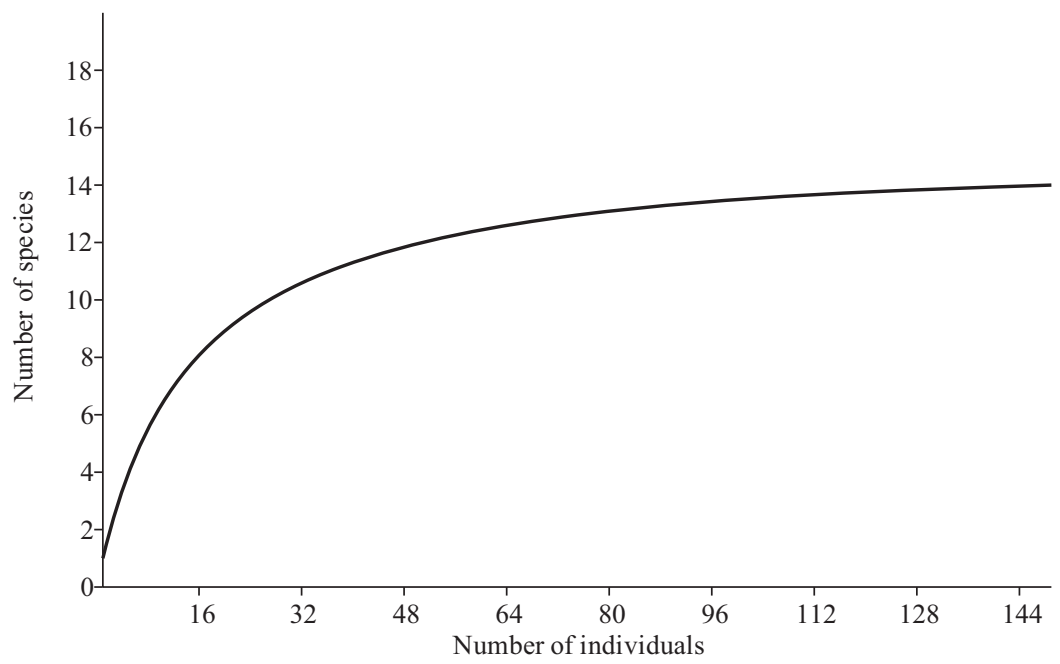

Figure 6. Rarefaction curve for non-flying small mammals (rodents and marsupials) sampled in live traps in the region of Jaíba, northern Minas Gerais state (captures inside roosts excluded). 


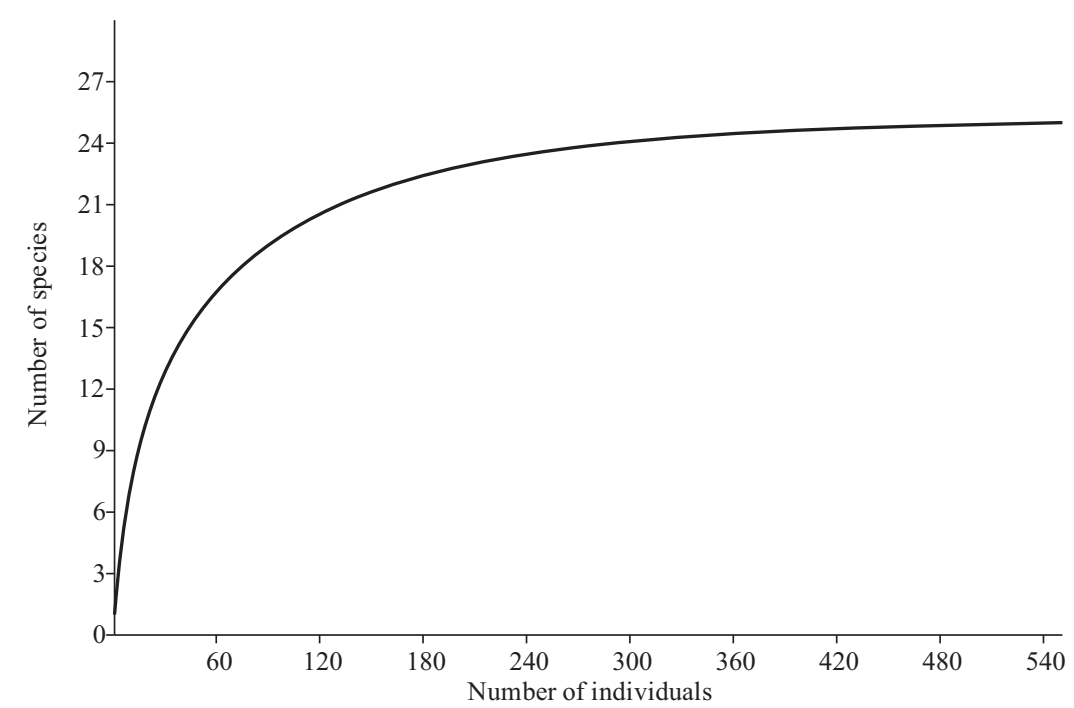

Figure 7. Rarefaction curve for bats sampled in mist nets in the region of Jaíba, northern Minas Gerais state (captures in front or inside roosts excluded).

Lorini et al. (1994), revealing an interesting pattern of semelparity previously unrecorded for the genus.

Monodelphis domestica (Wagner, 1842).

Voucher material (8): males - MN 28879, 28892, 29010, 29012, 29029, 34394, 81180; female - MN 34400.

Field notes: Captured at the Mata da Agroceres, Rebio Jaíba, and Fazenda Serra Azul.
Order Rodentia

Family Muridae

Calomys expulsus (Lund, 1841)

VOUCHER MATERIAL (21): males - MN 29002, 29004, 29005, 29017, 29021, 29025, 29032, 29040, 29042, 29048, 34420, 81143; females MN 29003, 29033, 29039, 29041, 29050; indet. - 43831-34.

Field notes: captured at Mata da Agroceres, Areas A, F, and C2, at Fazenda Serra Azul, and at the borders of Lagoa do

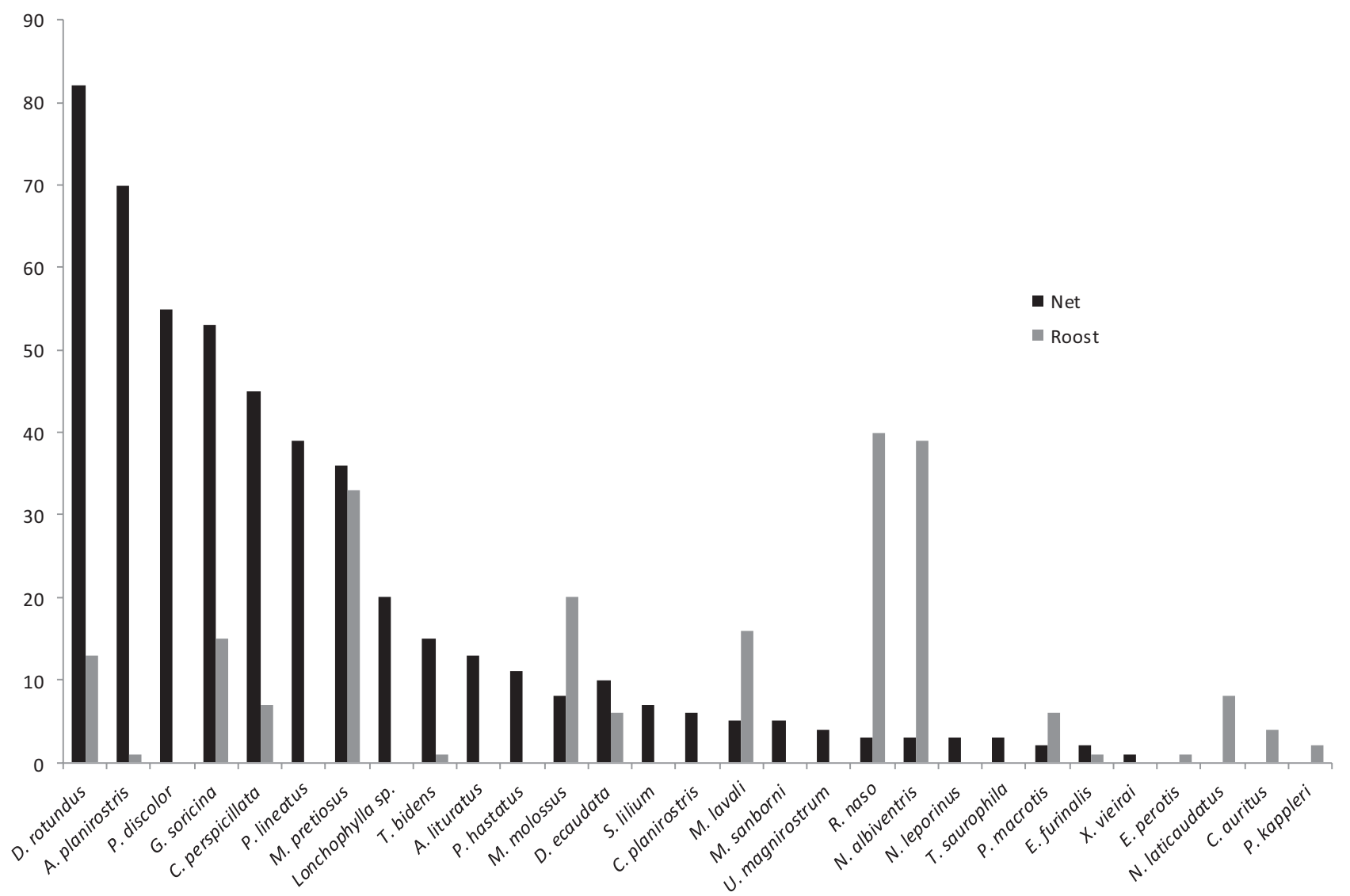

Figure 8. Capture numbers of bats sampled in mist nets in the region of Jaíba, northern Minas Gerais state (captures in front or inside roosts excluded). 


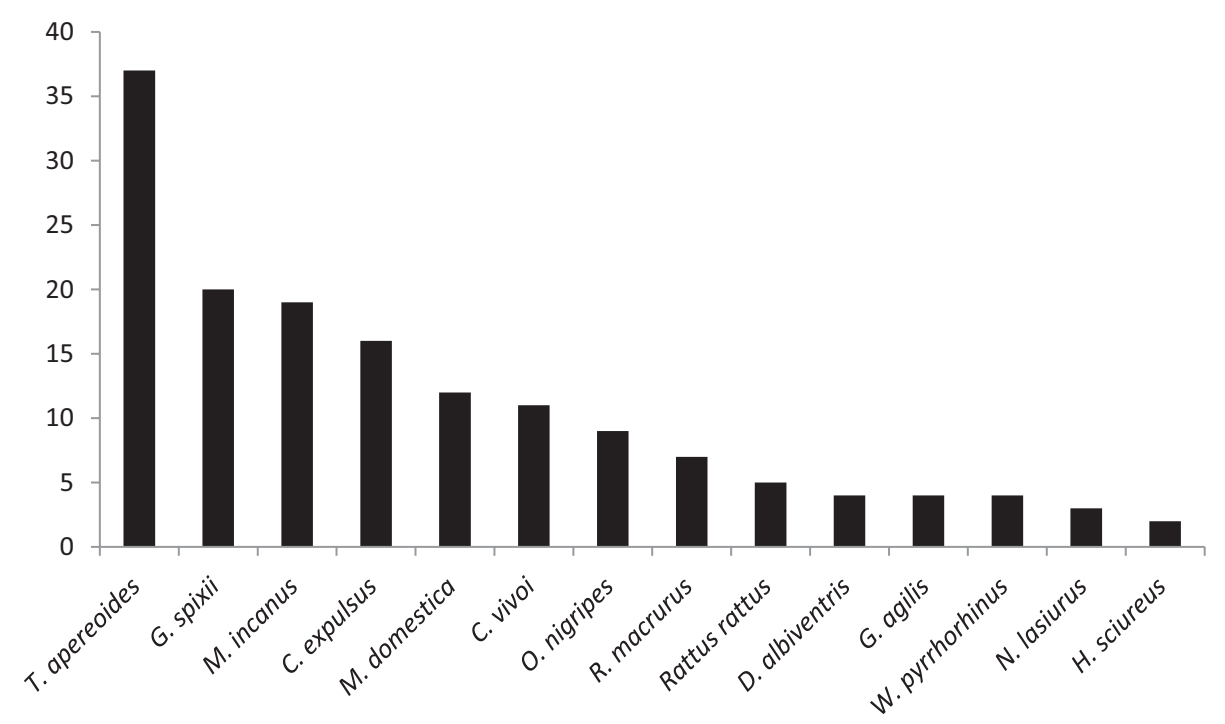

Figure 9. Capture numbers of non-flying small mammals (rodents and marsupials) sampled in live traps in the region of Jaíba, northern Minas Gerais state (captures inside roosts excluded).

Sossego, Dreno Jaíba, and Lagoa do Cajueiro during 1990. A female captured on August 21, 1990, in Area F had four embryos. Although fairly abundant during the field surveys in 1990 , this species was not recorded in Jaíba between 19921994, suggesting that local populations may alternate periods of abundance and reduction in subsequent years. The finding of old skeletons in cisterns, in the village of Mocambinho, in February 1993, may constitute additional evidence of a previous outbreak of this species in the Jaíba region.

Necromys lasiurus (Lund, 1841)

Voucher material (3): males - MN 29019, 29020, 29031.

Field NOTEs: captured close to the Lagoa do Sossego and at Dreno Jaíba. This otherwise ubiquous and abundant rodent was recorded in the humid areas near the Rio São Francisco in lower densities than other sigmodontines of similar size recorded in the region, Calomys expulsus and Oligoryzomys nigripes.

Oligoryzomys nigripes (Olfers, 1818)

VOUCHER MATERIAL (9): males - MN 29013-14, 29026, 2905152, 29055-56, 34018; female - MN 29038.
Field notes: captured at Mata da Agroceres, Dreno Jaíba, and Reserva Legal. Similarly to the pattern revealed for Calomys expulsus, most individuals were collected during July and August, 1990 in the more humid areas of Mata da Agroceres and Dreno Jaíba. The only exception was a specimen obtained in August 1992 in the Reserva Legal (Parque Florestal da Jaíba).

Cerradomys vivoi Percequillo, Hingst-Zaher \& Bonvicino, 2008 Voucher material (11): males - MN 29035, 34433, 34435, 34436, 43814, 43816, 46456; females - MN 29057, 34432, $34434,43815$.

Field Notes: captured at Dreno Jaíba and at riacho Mocambinho, humid areas near the Rio São Francisco. Abundance pattern of this larger sigmodont was different from those of the former three species, with more than $80 \%$ of the specimens being collected in 1993 .

TAхопомY: Six specimens were karyotyped (MN 34433, 34434, 34436, 43814, 43815, and 43816), revealing a diploid number $(2 \mathrm{n})$ varying between 50 and 52 , but with a constant fundamental number $(\mathrm{FN})=62$. This variability is due to

Table 1. Weight ( $\mathrm{g}$ ) and body measurements $(\mathrm{mm})$ of marsupials and rodents from the region of Jaíba, northern Minas Gerais state, southeastern Brazil. For each species we present mean values, range (in parentheses), and sample sizes.

\begin{tabular}{|c|c|c|c|c|c|}
\hline Species & Weight & Head-and-Body length & Tail length & Hindfoot (with claw) & Ear from notch \\
\hline Didelphis albiventris & $566.3(415.0-700.0) 4$ & $299.5(270.0-323.0) 4$ & $297.5(280.0-314.0) 4$ & $47.8(42.0-64.0) 4$ & $52.7(47.0-58.0) 4$ \\
\hline Gracilinanus agilis & $26.0(16.0-32.0) 3$ & $100.8(88.0-111.0) 4$ & $147.7(138.0-157.0) 4$ & $15.5(15.0-16.0) 4$ & $23.0(21.0-25.0) 4$ \\
\hline Marmosops incanus & $69.9(46.0-108.0) 10$ & $148.1(143.0-160.0) 10$ & $187.7(160.0-205.0) 9$ & $19.6(17.0-22.0) 10$ & $27.8(23.0-32.5) 10$ \\
\hline Monodelphis domestica & $49.3(39.0-64.0) 4$ & $123.7(120.0-126.0) 3$ & $86.0(75.0-87.0) 3$ & $20.3(20.0-21.0) 3$ & $18.3(16.5-20.0) 3$ \\
\hline Calomys expulsus & $23.2(21.0-41.0) 14$ & $86.4(72.0-105.0) 12$ & $73.1(51.0-77.0) 12$ & $18.8(15.0-21.5) 12$ & $13.9(12.0-15.8) 12$ \\
\hline Necromys lasiurus & $41.3(27.0-50.0) 3$ & $112.3(91.0-107.0) 3$ & $79.0(71.0-85.0) 3$ & $23.0(21.0-24.0) 3$ & $15.6(15.0-16.0) 3$ \\
\hline Oligoryzomys nigripes & $38(24.0-72.0) 7$ & $94.7(84.0-96.0) 6$ & $115.1(99.0-134.0) 7$ & $24.2(20.4-26.0) 6$ & $14.7(13.0-16.0) 7$ \\
\hline Cerradomys vivoi & $77.0(65.0-90.0) 10$ & $147.8(137.0-159.0) 11$ & $174.9(165.0-200.0) 11$ & $34.1(32.5-36.0) 11$ & $21.7(18.0-23.0) 11$ \\
\hline Holochilus sciureus & $87.0(75.0-100.0) 3$ & $151.0(144.0-158.0) 2$ & $131.0(123.0-139.0) 2$ & $37.5(37.0-38.0) 2$ & $16.5(16.0-17.0) 2$ \\
\hline Rhipidomys macrurus & $62.0(70.0-102.0) 4$ & $142.3(132.0-152.0) 5$ & $180-8(166.0-216.0) 4$ & $27.8(26.0-29.0) 5$ & $19.5(17.0-23.0) 5$ \\
\hline Wiedomys pyrrhorhinos & $41.3(28.0-51.0) 4$ & $115.8(108.0-122.0) 4$ & $184.8(160.0-197.0) 4$ & $26.5(26.0-27.0) 4$ & $20.3(19.0-22.0) 4$ \\
\hline Rattus rattus & $53.7(37.0-94.0) 3$ & $134.0(116.0-152.0) 2$ & $177.5(148.0-207.0) 2$ & $35(33.0-34.0) 2$ & $20.0(20.0-20.0) 2$ \\
\hline Galea spixii & $321.1(248.0-429.0) 14$ & $247.8(234.0-273.0) 14$ & - & $52.5(49.0-58.0) 12$ & $29.2(25.0-33.0) 14$ \\
\hline Thrichomys apereoides & $202.3(91.0-337.0) 17$ & $190.3(145.0-225.0) 23$ & 174.5 (146.0-203.0) 21 & $42.5(36.0-48.0) 22$ & $21.9(19.0-26.0$ (2) 22 \\
\hline
\end{tabular}


Nogueira, M. R. et al.

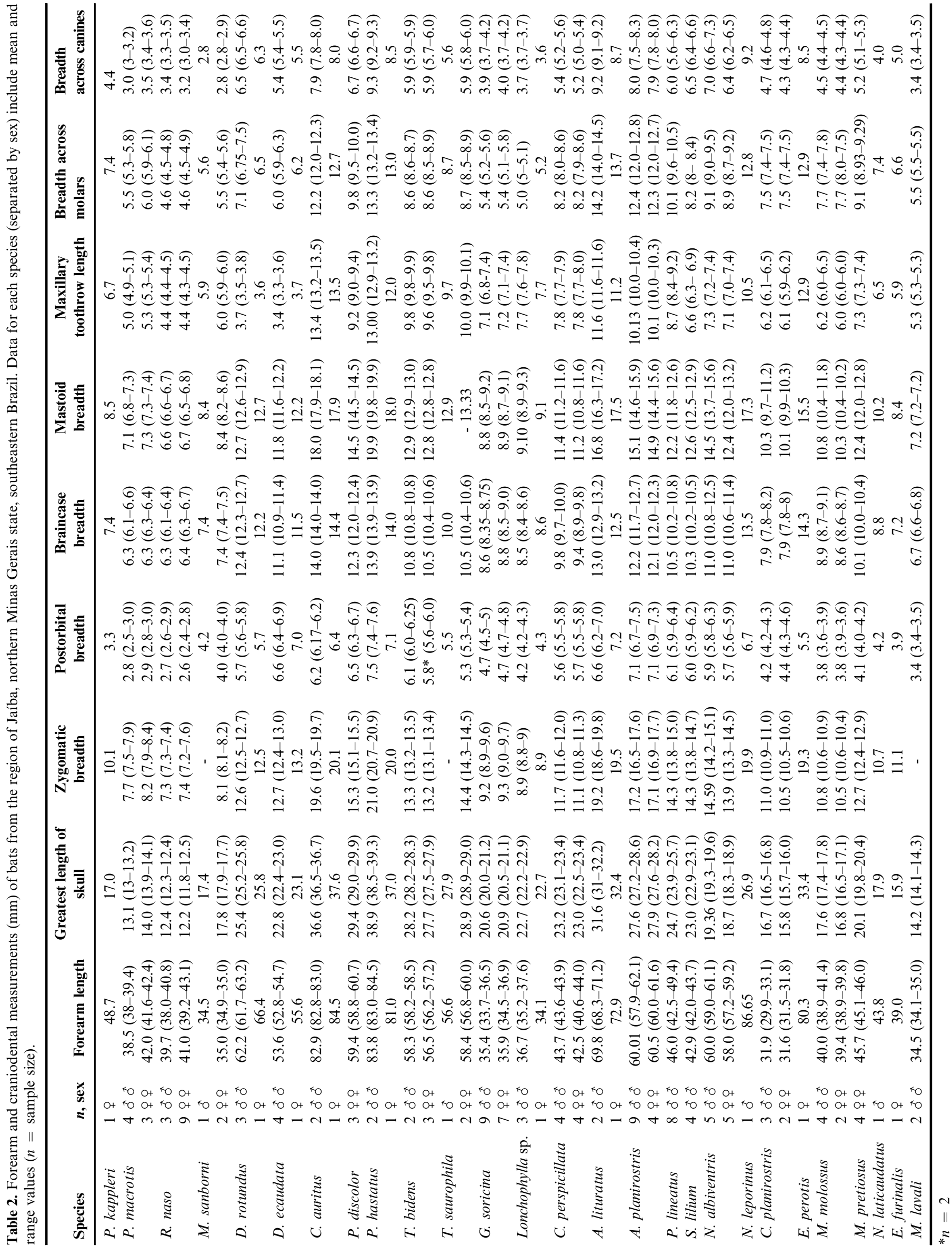


robertsonian rearrangments, the $2 \mathrm{n}=50$ karyotype presenting a median metacentric pair that is absent in the $2 \mathrm{n}=52$ karyotype, which by its turn presents two pairs of small acrocentric chromosomes, individuals with $2 \mathrm{n}=51$ being heterozygote with respect to this rearrange (Pessôa et al. 1994). Specimens MN 34432 - 35436 were designated as paratypes of Cerradomys vivoi by Percequillo et al. (2008).

Holochilus sciureus (Wagner, 1842)

Voucher material (4): males - MN 34419, 43825; females MN 81145; 81181.

FiELD NOTES: captured at Mocambinho (1) and at Lagoa do Sossego (3). The specimen from Mocambinho was collected from the mouth of a domestic cat.

TAXоnomy: Specimen MN 43825 was karyotyped, revealing $2 \mathrm{n}=56$ and $\mathrm{FN}=56$. This karyotype, together with the short hindfeet lacking the hypothenar pad, tail shorter than head and body, and the lophs/ids compressed with strongly acute, prismatic and sharp outer margins (Gonçalves et al. 2015), conform to the diagnostic characters of Holochilus sciureus among other similar species of the genus.

Rhipidomys macrurus (Gervais, 1855)

VOUCHER MATERIAL (8): males - MN 28874, 34408, 34410, 46563, 81142, 81174; females - MN 34409, 34429.

Field NOTES: captured at Area B, Mata da Agroceres, and Rebio Jaíba. The specimen MN 34429, captured in Mata da Agroceres on June 26, 1992, gave birth to two cubs in the next day, one of which lived in captivity for 14 months. TAXONOMY: Specimen MN 81174, a juvenile male collected in "Lagoa do Sossego" in August 11, 1993, showed 2n $=44$ and $\mathrm{FN}=48$, the karyotype composed of 18 pairs of acrocentric chromosomes, varying from large to small, a pair of submetacentric chromosomes of medium size, and 2 small metacentric pairs. The $\mathrm{X}$ chromosome is a large submetacentric and the $\mathrm{Y}$ is a small acrocentric (Corrêa and Pessôa, 1996).

Wiedomys pyrrhorhinos (Wied-Neuwied, 1821)

VOUCHER MATERIAL (4): males - MN 34413, 62180, 62081; female - MN 34412.

FIELD NOTES: captured only at the Rebio Jaíba, the driest section of the Jaíba region. This species was only recorded in the 1992-1993 field surveys.

TAXONOMY: The longer molar toothrow, the broader incisive foramina, and the lack of the alisphenoid strut in the specimens from Jaíba conform to the recognized distinctive characters of $W$. pyrrhorhinos with respect to $W$. cerradensis, a species described from Jaborandi, Bahia, by Gonçalves et al. (2005).

Rattus rattus (Linnaeus, 1758)

Voucher material (5): males - MN 29046, 29047, 29053, 34421; female - MN 29045.

FIELD NOTES: captured inside or near residences in Mocambinho $(n=1)$ and in the Area F $(n=3)$, but also at the Rebio Jaíba $(n=1)$, in a road crossing the biological reserve. It is interesting to note that the record from Rebio Jaíba was obtained in a region distant from any human settlement, a relatively unusual condition for Rattus, and may be due to its accidental transportation along the dirt road that crossed the reserve.
Family Erethizonthidae

Coendou prehensilis (Linnaeus, 1758)

VOUCHER MATERIAL (1): MN 29080.

FIELD NOTES: spines that allowed the identification of this species were obtained from a hunter from Fazenda Santa Idália, municipality of Matias Cardoso.

Family Dasyproctidae

Dasyprocta azarae Lichtenstein, 1823

Voucher material (1): MN 29059.

FIELD NOTES: the skin of a specimen collected at Area A was obtained from a hunter.

Family Caviidae

Galea spixii (Wagler, 1831)

VOUCHER MATERIAL (18): males - MN 29018, 29064, 29065, 29069, 29072, 34414-15, 43811; females - MN 29068, 29070, 29071, 34414, 34416, 34417, 34437, 43813, 43817, 43818.

FIELD NOTES: captured in an area close to the Lagoa do Sossego and at the Rebio Jaíba. This species was usually spotted at night at margins of dirt roads, in groups of several individuals. Of five specimens trapped (three of them released) in November 1993, four were pregnant, with one embryo each. Nursing females had been captured in February of the same year.

Family Echimyidae

Thrichomys apereoides (Lund, 1839)

VOUCHER MATERIAL (34): males - MN 28878, 28880-82, 28885, 29022, 29034, 29067, 34404, 59444-46, 81140-141; females MN 28872-73; 28877, 28883-84, 29007, 29009, 29015-16, 29023, 29036-37, 29044, 29066, 29067, 34405, 34407, 46599; indet. - MN 29011, 81139.

FIELD NOTES: sampled at the Mata da Agroceres, Dreno Jaíba, and Rebio Jaíba, living under dead trunks of fallen trees, and in tree holes. Six additional individuals captured in the limestone outcrops of Fazenda Serra Azul were released. Pregnant females were captured in March, July, and August 1990, and in August 1992. An individual that was already adult when trapped (MN 81141) lived additional four years in captivity.

TAхоломy: A karyotyped specimen, a female (MN 34407) captured in Parque Florestal da Jaíba in 21/08/1992, showed $2 \mathrm{n}=30$ and $\mathrm{NF}=54$ comprising 12 pairs of metacentric, one pair of submetacentric, and one acrocentric pair. The first pair carries a large interstitial secondary constriction on the short arm (Pessôa et al. 2004). This karyotype differed from the topotypical $T$. apereoides karyotype $(2 \mathrm{n}=28, \mathrm{FN}=50)$, but we tentatively assign the Jaíba population to this species, pending a better sampling of the karyological variation in the geographic range assigned to this species.

Phyllomys blainvilii (Jourdan, 1837)

VOUCHER MATERIAL (1): MN 43810.

FiELD NOTES: A juvenile female captured by hand in the ground, crossing a dirt road, at 8:00 PM, at the region of Dreno Jaíba. This arboreal species may occasionally use the ground when moving across forest remnants. As it lacks adaptations for cursorial escape, it becomes immobile at first and attempts to escape if the predator relaxes its concentration. It is then easily captured by hand in such circumstances. 
Order Chiroptera

Family Emballonuridae

Peropteryx kappleri Peters, 1867

Voucher material (1): female - ALP 6980.

FIELD NOTES: sampled only at the limestone outcrop of the Fazenda Serra Azul. Two individuals were captured at cave entrances. One of them was previously roosting with another P. kappleri in a small cavity formed by the roots of a Ficus tree, at $1.70 \mathrm{~m}$ from the ground.

\section{Peropteryx macrotis (Wagner, 1843)}

Voucher material (8): males - ALP 6939, 6969, 6981-83; females - ALP 6858, 6904, 6988.

TAXonomy: the small, dark-winged specimens of Peropteryx from Jaíba (FA < $43 \mathrm{~mm}$, MTL $<5.7 \mathrm{~mm}$; Table 2) were promptly differentiated from the larger P. kappleri (FA $>45$ mm, MTL > $6.5 \mathrm{~mm}$; Hood \& Gardner 2008), but present measurements that could be referred to both Peropteryx trinitatis Miller, 1899 and $P$. macrotis, since there is overlap in the mensural characters currently used in the diagnosis of these taxa (Hood \& Gardner 2008). According to Simmons \& Voss (1998) and Lim et al. (2010), in addition to its larger size, P. macrotis presents a posterior accessory cusp in the anterior upper premolar, while in $P$. trinitatis this tooth is peg-like. Hood \& Gardner (2008) also included this latter character in their key to South American Peropteryx, but reported that a distinct posterior accessory cuspule is not always present in P. macrotis. In our sample, most specimens present a posterobasal extension in the anterior upper premolar, clearly forming a cuspule in ALP 6982 and 6969 . We retain here our original identification of these specimens as $P$. macrotis (Oliveira et al. 2003), but we also recognize that the limits between the small dark-winged species of Peropteryx have yet to be further investigated.

FIELD NOTES: 12 individuals were captured (two at roosts), all at the limestone outcrop of Fazenda Serra Azul. Single individuals and small groups ( $2-5$ bats) were frequently observed at cave entrances. Two individuals, apart $1.5 \mathrm{~m}$ from each other, were found at the entrance of a cave where more than $150 \mathrm{D}$. rotundus were roosting.

Rhynchonycteris naso (Wied-Neuwied, 1820)

Voucher material (21): males - ALP 6844, 6918, 6931, 6933, MN 28870; females - ALP 6845, 6850, 6919, 6924, 6925, 6927, 6929, 6930, 6934-38, MN 29049, 46448, 28871.

FIELD NOTES: found under wood and concrete bridges associated to the riacho Mocambinho, lagoons, and irrigation channels. Only three, out of 44 individuals, were captured in nets away from known roosts. For details, see Nogueira \& Pol (1998).

Family Phyllostomidae

Subfamily Micronycterinae

Micronycteris sanborni Simmons, 1996

Voucher MATERIAL (5): male - ALP 6860; females - ALP 6822, 6823, 6833, 6859.

TАхолому: the record of Micronycteris minuta for Jaíba, in the compilation of Oliveira et al. (2003), is based on the specimens reported here. They present a truly white ventral pelage coloration, not seen in any other pale-bellied Micronycteris (Simmons 1996), and their calcar is similar in size to their foot, which is another useful diagnostic feature of this species (Williams \& Genoways 2008). We noticed, however, that the specimens from Jaiba are somewhat larger, in cranial length, than the specimens in the type series (e.g. condyloincisive length 15.7 vs. $15.16 \mathrm{~mm}$; Table 2).
Additionally, the diastema between the outer upper incisor and the canine, a diagnostic character of $M$. sanborni, was absent in specimen ALP 6833 and relatively small in the other specimens, when compared to the holotype (Simmons, 1996). Considering the small sample available for the description of $M$. sanborni (six specimens; Simmons [1996]), we interpret these discrepancies as representing within-species variation. This supposition is also supported by the examination of a larger series of $M$. sanborni from the state of Ceará (e.g. ALP 2958, ALP 3639-40; M.R. Nogueira, unpublished data), in which the same diastema proved to be subject to some variation (the same for the second diastema, between the first and second upper premolars). This series is particularly interesting for the understanding of character variation in $M$. sanborni because all specimens were obtained from a single colony, in a crevice located in the wall of a sugar cane mill.

FIELD NOTES: six individuals were captured, all at the limestone outcrop of the Fazenda Serra Azul. Three katydids (Orthoptera) measuring about $7 \mathrm{~mm}$ each and two moths (Lepidoptera) with about $10 \mathrm{~mm}$ were offered to and promptly accepted by a single $M$. sanborni briefly kept captive.

Subfamily Desmodontinae

Desmodus rotundus (É. Geoffroy, 1810)

Voucher material (6): males - ALP 6872, 6941, 6970, MN 42740; females - ALP 6973, MN 42741.

FIELD NOTES: 100 individuals were captured, all at the Fazenda Serra Azul. A colony estimated in 150 individuals was found in a cave, the entrance of which was used as roost by P. macrotis. Nine $D$. rotundus were captured in a net set at the entrance of another cave, where we also sampled $C$. auritus, T. bidens, C. perspicillata, G. soricina, D. ecaudata, and M. lavali. We found pregnant females in April (2) and May (1), and lactating females in February (1) and April (1).

Diphylla ecaudata Spix, 1823

Voucher material (6): males - ALP 6867, 6977, 6978, 6992; females - ALP 6836, MN 42742.

FIELD NOTES: from the 14 individuals of $D$. ecaudata sampled, 13 were obtained at the Fazenda Serra Azul and one at Area F. In this latter site, individuals were captured in a net set close to a tree used as perch by helmeted guinea fowls (Numida meleagris) that had been attacked in the previous nights. At Serra Azul, five individuals were captured at the entrance of a cave in the same net we captured $C$. auritus, $T$. bidens, $C$. perspicillata, G. soricina, D. rotundus, and M. lavali.

Subfamily Phyllostominae

Chrotopterus auritus (Peters, 1856)

Voucher material (4): males - ALP 6818, 6819, 6820; female ALP 6821.

FIELD NOTES: sampled only at the limestone outcrop of the Fazenda Serra Azul. A male was captured in a mist net set at the entrance of a cave, where we also captured T. bidens, C. perspicillata, G. soricina, $D$. rotundus, $D$. ecaudata, and $M$. lavali. The three additional individuals were obtained in a diurnal sampling inside another cave.

Phyllostomus discolor (Wagner, 1843)

Voucher material (13): males - ALP 6827, MN 42731, 42733, 42735, 42737; females - ALP 6852-53, 6965, MN 42732, 42734, 42736, 42738, 46446.

FIELD NOTES: two individuals captured in mist nets set adjacent to a cattle pond at Fazenda Solagro, one at the Reserva 
Biológica do Jaíba, and 52 close to the Rio São Francisco, either at CAM, in nets set close to flowering shrubs of Calliandra sp. (Leguminosae, Mimosoideae), or in the Mata da Agroceres, near the village of Mocambinho. While feeding at the flowers of Calliandra sp., $P$. discolor landed over them. Abundant pollen was found over the head of most bats and at the ventral surface of their patagium. Lactating females were captured in March (1), April (15), and May (2). A pregnant female was found in May.

Phyllostomus hastatus (Pallas, 1767)

Voucher MATERIAL (4): males - ALP 6866, 6869; females - ALP 6900, MN 42739.

FIELD NOTES: 11 individuals were captured, three at Area F, close to banana plantations, six at CAM, one at Dreno Jaíba, in the border of the forest, and one in Mocambinho. A lactating female was sampled in October.

Tonatia bidens (Spix, 1823)

Voucher material (6): males - ALP 6832, 6843; females - ALP 6837, 6838, 6839, 6842.

FIELD NOTES: all 16 individuals obtained were captured at Fazenda Serra Azul. One individual was obtained at the entrance of a cave where we also captured $C$. auritus, $C$. perspicillata, G. soricina, D. rotundus, D. ecaudata, and $M$. lavali. Some insects were offered to individuals briefly kept captive. Katydids (Orthoptera) ranging from 1 to $5 \mathrm{~cm}$ and beetles (Coleoptera) from 0.5 to $2 \mathrm{~cm}$ were promptly accepted. A lactating female was captured in March.

\section{Tonatia saurophila Koopman \& Williams, 1951}

Voucher MATERIAL (3): male - ALP 6817; females - ALP 6854, 6855.

TAxonomy: listed as Tonatia sp. in the compilation of Oliveira et al. (2003) for Jaíba. These specimens present the diagnostic characters described by Williams et al. (1995), including a relatively large gap between the internal basis of the lower canines (when compared to $T$. bidens), a secondary process in the mastoid, which partially covers the auditory bullae, and a well-developed (also in comparison to T. bidens) second lower premolar, only slightly obscured by the cingulum of the adjacent premolar. These specimens also present a white stripe on the top of the head, between ears, although in one specimen this stripe was almost indistinct. Measurements are also generally within the variation described by Williams et al. (1995) for Tonatia s. maresi, the geographical distribution of which extends into the Caatinga biome.

FIELD NOTES: one specimen was obtained at the Fazenda Serra Azul and two at Rebio Jaíba. At this latter site, one specimen was captured in a trail inside the forest and the other over a relatively large puddle (ca. $5 \mathrm{~m}$ across) formed by rainwater and located at the road that borders the reserve. Other species captured at the same puddle were E. furinalis, C. planirostris, M. pretiosus, and M. molossus.

\section{Subfamily Glossophaginae}

\section{Glossophaga soricina (Pallas, 1766)}

VOUCHER MATERIAL (25): males - ALP 6870, 6881, 6886, 6888, 6890, 6902, 6905, 6984, MN 42752, 42759, 43248; females ALP 6891, 6895, 6940, 6968, 6985-87, MN 42753, 42755-58, 46447.

FIELD NOTES: one of the most common bat species in the region. A total of 68 individuals were obtained at the following sites:
Fazenda Serra Azul (46), CAM (8), Area F (5), Rebio Jaíba (3), Area B (1), Area C2 (1), Fazenda Yamada (1), Dreno Jaíba (1), Lagoa do Sossego (1), and Mata da Agroceres (1). Two colonies of $G$. soricina, each with five individuals, were found in small cavities at Fazenda Serra Azul. In another cave, a single individual was found in cohabitation with three $P$. lineatus. Eight individuals were captured at the entrance of a cave in the same net we captured $C$. auritus, $T$. bidens, $C$. perspicillata, $D$. rotundus, $D$. ecaudata, and $M$. lavali. We also recorded a roosting group of eight $G$. soricina (three of which were captured) in the attic of the Rebio Jaíba headquarter. All individuals captured at CAM were obtained close to flowering shrubs of Calliandra sp., and two of them presented abundant pollen spread over the ventral surface of their wing membrane. A pregnant female was found in April and a lactating in March. This latter individual was carrying a newborn when captured in a mist net at Fazenda Serra Azul.

Subfamily Lonchophyllinae

Lonchophylla sp.

Voucher material (5): males - ALP 6841, 6908, 6909, MN 42754; females - ALP 6840.

TAXоNOMY: individuals of Lonchophylla sp. from Jaíba present a pale yellowish-brown ventral pelage that clearly distinguished them from syntopic $G$. soricina and $X$. vieirai in the field. We initially identified these specimens as L. mordax, but ongoing taxonomic research on this group revealed that they might belong to a distinct new species (R. Moratelli, pers. comm.).

FIELD NOTES: one individual captured at CAM and 18 at the limestone outcrop of the Fazenda Serra Azul. Lactating females were obtained in April (6) and May (1), and a pregnant female was found in April.

Xeronycteris vieirai Gregorin \& Ditchfield, 2005

Voucher material (1): female - ALP 6824.

TAXONOMY: a detailed account on the morphology of this specimen and a revised diagnosis for the genus were presented elsewhere (Nogueira et al. 2014b).

FIELD NOTES: a single individual captured at the limestone outcrop of the Fazenda Serra Azul. When this individual was captured, unidentified pollen was found covering its head, confirming the nectar-feeding habits expected for this species based on its craniodental morphology and phylogenetic affinities.

\section{Subfamily Carolliinae}

Carollia perspicillata (Linnaeus, 1758)

Voucher MATERIAL (21): males - ALP 6865, 6880, 6882, 6889, 6972, 6994, MN 42730, 42750; females - ALP 6828, 6883, 6884, 6907, 6950, 6951, 6989, 6991, 6993, 6995, MN 42728, 42729, 42748. FIELD NOTES: a widely distributed species in the Jaíba region. Samples were obtained at the Fazenda Serra Azul (43), Fazenda Yamada (4), CAM (2), Fazenda Solagro (2), Area F (2), Gleba C2 (1), and Rebio Jaíba (1), where it was captured at the margins of a swamp area called "Lagoa Santa". It was also found roosting inside an abandoned cistern, close to the headquarters of the reserve. Three specimens were found in a cluster at this roost. At the Fazenda Serra Azul, two individuals were obtained at the entrance of a cave where we also captured $C$. auritus, $T$. bidens, G. soricina, D. ecaudata, and M. lavali. Lactating females were found in March (1), April (1), and October(1). 
Subfamily Stenodermatinae

Artibeus lituratus (Olfers, 1818)

Voucher MATERIAL (3): males - ALP 6862, 6868; female - ALP 6864.

Field NOTES: one individual captured at Fazenda Solagro, two at the Fazenda Serra Azul, and 10 at Area F.

\section{Artibeus planirostris (Spix, 1823)}

Voucher MATERial (16): males - ALP 6879, 6892, 6893, 6906, 6957, 6958, 6976, 6979, 6990, MN 43250; females - ALP 6861, 6863, 6887, 6956, MN 42743-44.

TAхолому: the record of Artibeus sp. for Jaíba, in the compilation of Oliveira et al. (2003), is based on this material. All 13 specimens from which the skulls were removed were found to present a third small upper molar. These specimens were also referable to $A$. planirostris on the basis of their pale brown ventral pelage, inconspicuous facial stripes, horseshoe of the noseleaf centrally free from the upper lip, and nearly naked dorsal surface of the uropatagium. In Artibeus obscurus, which is similar in size to A. planirostris, the fur is blackish and the third small upper molar is absent in populations from eastern Brazil (Taddei et al. 1998).

FiELD NOTES: a frequent species at Jaíba, with captures at the Fazenda Serra Azul (58), Area F (7), Fazenda Solagro (4), Fazenda Yamada (1), and CAM (1). Lactating females were captured in April (2), October (1), and November (1).

Platyrrhinus lineatus (É. Geoffroy, 1810)

Voucher MATERIAL (10 males): ALP 6829, 6830, 6871, 6894, 6903, 6954, 6955, 6971, MN 42745-6.

TAXONOMY: the smallest specimen in our sample (ALP 6971) presents the forearm out of the range described for $P$. lineatus, conforming better to data available for Platyrrhinus recifinus (Thomas, 1901). Based on the morphology of its first lower premolar, pattern of dorsal pelage coloration, and presence of interramal vibrissae, however, we identify it as $P$. lineatus (Velazco 2005, Velazco et al. 2010). Although smaller, this specimen is similar in external morphology and skull shape to other $P$. lineatus in our sample from Jaíba.

FIELD NOTES: among the 39 individuals captured, 34 were obtained at Fazenda Serra Azul, where three individuals were found roosting in a small cave. Additional individuals were obtained at the Fazenda Solagro and at the lote agrícola. A single $G$. soricina was found in the same cave $P$. lineatus was using as roost at the Fazenda Serra Azul. One lactating female was captured in March and another in April.

Sturnira lilium (É. Geoffroy, 1810)

Voucher material (7): males - ALP 6885, 6910, 6952, 6953, 6975, MN 42727; female - ALP 6899.

FIELD NOTES: among the seven individuals obtained, three were captured at the Dreno Jaíba, two at the Fazenda Solagro, one in a trail at the Fazenda Yamada, and one at Gleba C2, $30 \mathrm{~km}$ distant from Mocambinho. A lactating female was obtained in October.

Uroderma magnirostrum Davis, 1968

Voucher MATERIAL (3): males - ALP 6831, 6834; female - ALP 6835 .

TAXONOMY: data from these specimens were presented elsewhere (Nogueira et al. 2003).
FIELD NOTES: four individuals were captured, all at the limestone outcrop of the Fazenda Serra Azul. For details, see Nogueira et al. (2003).

Family Noctilionidae

Noctilio albiventris Desmarest, 1818

VOUCHER MATERIAL (14): males - ALP 6846, 6847, 6848, 6923, 6932, 6997; females - ALP 6920, 6921, 6922, 6926, 6928, 6962, 6967, 6996.

FIELD NOTES: sampled mainly at the riacho Mocambinho (39 individuals), where a wooden bridge was used as secondary (nocturnal) roost. The same bridge was used as roost by $R$. naso (Nogueira \& Pol 1998). Three other specimens were captured in mist nets set over the cattle pond at Fazenda Solagro. Reproductive data as well as more detailed sampling information can be found elsewhere (Nogueira \& Pol 1998).

Noctilio leporinus (Linnaeus, 1758)

Voucher material (1): male - ALP 6849.

FIELD NOTES: two specimens were collected in a net set over the riacho Mocambinho and one over the cattle pond at Fazenda Solagro. This species was frequently observed foraging over the water at the Rio São Francisco, irrigation channels, and cattle ponds (Fazenda Solagro). A group estimated in 50 individuals was found roosting under a concrete bridge that crosses one of the irrigation channels. This roost, however, was used only during the night, when three specimens of $R$. naso could also be found, separated about $5 \mathrm{~m}$ from the clusters of $N$. leporinus.

Family Molossidae

Subfamily Molossinae

Cynomops planirostris (Peters, 1866)

VOUCHER MATERial (5): males - ALP 6856, 6948, 6949; females ALP 6897, 6947.

FIELD NOTES: six individuals were captured, all in nets set over or adjacent to water bodies. Four specimens were obtained at the cattle pond in Fazenda Solagro, one over a puddle in the road adjacent to the Rebio Jaíba, and one at the Dreno Jaíba. A pregnant female with an embryo measuring $16.55 \mathrm{~mm}$ was captured in November.

\section{Eumops perotis (Schinz, 1821)}

VOUCHER MATERIAL (1): MN 46478.

Measurements: FL, 80.25; GLS, 33.38; CBL, -; ZB, 19.28; PB, 5.48; BB, 14.26; MB, 15.51; MTL, 12.91; BAM, 12.86; BAC, 8.47. FIELD NOTES: a female was collected by hand, in the early morning, when it was roosting on the wall of a building at the margin of an irrigation channel at Frente $3\left(15^{\circ} 07^{\prime} 36^{\prime \prime} \mathrm{S}\right.$, $44^{\circ} 00^{\prime} 43^{\prime}$ 'W), a small village.

\section{Molossus molossus (Pallas, 1766)}

Voucher MATERIAL (8): males - ALP 6876, 6916, MN 4707981; females - ALP 6873, MN 47082, 47090.

TAXоNOMY: some small Molossus from Jaíba (MN 4707947082, MN 47090) have been reported in the literature as Molossus currentium Thomas, 1901 (Tavares et al. 2010). However, these specimens, as well as others we have collected in the same region, present relatively long (ca. $5 \mathrm{~mm}$ ) and bicolored dorsal fur (in M. currentium it is short and with no bands; Gregorin et al. 2011b), relatively narrow braincase (males with $8.71-9.14 \mathrm{~mm}$ vs. $9.3-10.6 \mathrm{~mm}$ in $M$. currentium; Gregorin et al. 2011b), and short skull (males with 17.39-17.79 
mm vs. $19.2-20.3 \mathrm{~mm}$ in M. currentium; Gregorin et al. 2011b) and forearm (males with $38.87-41.4 \mathrm{~mm}$ vs. $41.0-44.0 \mathrm{~mm}$ in M. currentium; Gregorin et al. 2011b). As in the case of $M$. pretiosus (see below), we found variation in the shape of the upper inner incisors. In some specimens (e.g. ALP 6851 and $\mathrm{MN}$ 47080) these teeth are pincer-like, as described for M. molossus, while in others they are spatulate, as seen in M. currentium (Gregorin et al. 2011b). This latter condition, however, seems to be the result of a wear of these teeth.

Molossus aztecus Saussure, 1860 was recently reported for Brazil based on specimens from Minas Gerais, but in this species the braincase is wider than in $M$. molossus (like in $M$. currentium) and the basal band of the dorsal fur is shorter than in this latter species (1/3 to $1 / 4$ vs. 1/2) (Gregorin et al. 2011b). In our specimens, the basal white band comprises $1 / 2$ of the length of the hairs. We, therefore, recognize the small Molossus from Jaíba as $M$. molossus. It is noteworthy, however, that these specimens are consistently paler than specimens from moister areas we have examined.

FIELD NOTES: among the 28 sampled individuals, three were obtained in a net set crossing a relatively large puddle (ca. $5 \mathrm{~m}$ across) in the road that borders the Rebio Jaíba, four were captured around residences at the CAM area, one in a net set over the riacho Mocambinho, and 20 in roofs of residences at Mocambinho. At the Rebio Jaíba, in the same net we sampled M. molossus we also captured $T$. saurophila, E. furinalis, $M$. pretiosus, and $C$. planirostris. At Mocambinho, we found $M$. molossus sharing four roofs with $M$. pretiosus, and in one of them $N$. laticaudatus was also present. Pregnant females with one embryo each were recorded in October 1992 (2) and October 1994 (1), the last one measuring $16.8 \mathrm{~mm}$.

Molossus pretiosus Miller, 1902

VOUCHER MATERIAL (42): males - ALP 6826, 6875, 6896, 6898, 6913, 6942, 6943, MN 22862, 47084; females - ALP 6874, 6877, 6878, 6911, 6912, 6914, 6915, 6917, 6944, 6945, 6946, 6963, 6964, 6966, MN 28863-69, 29028, 47074-47078, 47083, 47085-47089. TAXONOMY: all large specimens of Molossus from Jaíba are here recognized as $M$. pretiosus. Measurements obtained for the four females from Museu Nacional cited as Molossus rufus É. Geoffroy, 1805 by Tavares et al. (2010) (MN 47074-77; Table 2) follow the same pattern described by Nogueira et al. (2008) for other M. pretiosus from Jaíba.

FIELD NOTES: widespread at the Jaíba region. All specimens not previously cited by Nogueira et al. (2008) were captured in roofs at Mocambinho.

Nyctinomops laticaudatus (É. Geoffroy, 1805)

Voucher material (1): male - ALP 6825.

FIELD NOTES: a single specimen was captured in a mist net set close to the entrance of a roost in the roof of a residence at the CAM. Seven additional individuals were captured by hand inside another roost in the roof of a residence at Mocambinho. The number of individuals estimated to be present at this roost was 40. Other species occupying this same roost were $M$. molossus and $M$. pretiosus. A lactating female was found in May.

Family Vespertilionidae

Subfamily Vespertilioninae

Eptesicus furinalis (d'Orbigny \& Gervais, 1847)

Voucher material (3): males - MN 29027, ALP 6824 (only

skull available); female - ALP 6857.
FIELD NOTES: two specimens were obtained at Dreno Jaíba and one at Rebio Jaíba. In this latter site, the bat was captured in a net set over a puddle in the road adjacent to the Reserve. In the same net we captured $E$. furinalis at Rebio Jaíba, we also captured T. saurophila, C. planirostris, M. pretiosus, and $M$. molossus. The female captured in October was lactating.

\section{Subfamily Myotinae}

Myotis lavali Moratelli, Peracchi, Dias \& Oliveira, 2011

Voucher material (3): males - ALP 6901, 6974; female - MN 42747.

TAxonomy: cited as Myotis sp. in the compilation of Oliveira et al. (2003) for Jaíba. The strongly bicolored dorsal fur (mediumbrown bases and light-brown tips) and upwardly oriented anterior rostrum found in our specimens are typical of M. lavali (Moratelli \& Wilson 2013).

FIELD NOTES: among the 21 individuals sampled, 17 were captured in the limestone outcrop of the Fazenda Serra Azul; 16 in a net set close to the entrance of a cave, where we also captured C. auritus, T. bidens, G. soricina, C. perspicillata, D. rotundus, and $D$. ecaudata. From the four additional individuals, two were captured in nets set over a cattle pond at the Fazenda Solagro and two at Dreno Jaíba.

\section{Discussion}

Currently, 122 small mammals are assigned to the Caatinga biome, including seven didelphimorph marsupials, 35 rodents, and 80 bats (Paglia et al. 2012, Sá-Neto \& Marinho-Filho 2013). The region of Jaíba, with the 46 species reported here, harbors at least $40 \%$ of this fauna. If we consider the whole mammalian fauna of Jaíba, and add to our list the 13 medium to large species recorded by Oliveira et al. (2003), this region can be recognized as harboring $38 \%$ of the mammalian fauna in the Caatinga (156 species; Paglia et al. 2012, Sá-Neto \& Marinho-Filho 2013). With at least 59 species, the mammalian fauna of Jaiba can be recognized as one of the richest in the Caatinga, a conclusion anticipated by Oliveira et al. (2003) and confirmed here with the addition of some new records.

Among the 10 endemic mammalian species currently recognized for the Caatinga (Paglia et al. 2012), at least two (Wiedomys pyrrhorhinos and Xeronycteris vieirai) are found in Jaíba, and three species that are endemic to the diagonal of dry open formations that crosses South America are also represented in this region (Rhipidomys macrurus, Thrichomys apereoides, and Micronycteris sanborni). Although Micronycteris sanborni has been also reported to occur in the Brazilian Amazon (López-Baucells et al. 2013), this record has been disregarded due to the lack of an associated voucher (Nogueira et al. 2014a). Jaíba also remain as the single region in the Caatinga where Molossus pretiosus has been recorded (Nogueira et al. 2008), and its terrestrial mammal fauna includes interesting additional components, such as the didelphid Marmosops incanus and the echimyid Phyllomys blainvilii. The former is best known from coastal Atlantic forest localities ranging from Bahia to São Paulo, with a few inland samples in Caatingas of Bahia and Minas Gerais (Mustrangi \& Patton 1997), and the latter is also known in the Caatinga from scattered localities in isolated areas of semideciduous forest islands (Leite 2003). Some bat species previously reported for Jaiba, however, had their records revised. Specimens supporting the occurrence of Lonchophylla mordax and Micronycteris minuta 
(Oliveira et al. 2003) were assigned here as Lonchophylla sp. and M. sanborni, respectively, and those reported as Molossus currentium and Molossus rufus by Tavares et al. (2010) were identified, respectively, as $M$. molossus and M. pretiosus.

A total of 84 bat species are currently reported for the state of Minas Gerais (Nogueira et al. 2008, Tavares et al. 2010, Gregorin \& Loureiro 2011, Gregorin et al. 2011b, Carvalho et al. 2013, Falcão et al. 2014, Velazco et al. 2014, Gregorin et al. 2015), but only 19 are assigned to caatinga regions (Nogueira et al. 2008, Tavares et al. 2010, Falcão et al. 2014). The present results increase to 34 the number of bat species recorded for the caatinga of Minas Gerais, including $T$. saurophila, $X$. vieirai, and $M$. lavali, new records also for the state of Minas Gerais. We also provide the first vouchersupported record of $M$. sanborni for Minas Gerais (Falcão et al. [2014] did not collect specimens in their sampling) and significantly extend the known range of $X$. vieirai. This latter species had its previous southernmost locality in the municipality of Cocorobó, state of Bahia (ca. $800 \mathrm{~km}$ from Jaíba), and $M$. sanborni is already known from Pantanal (Santos et al. 2010), but in eastern Brazil its previous southernmost vouchersupported record comes from Estação Ecológica Serra Geral do Tocantins, state of Tocantins (ca. $600 \mathrm{~km}$ from Jaíba) (Gregorin et al. 2011a). The bat fauna of Minas Gerais can now be recognized as including 86 species. This total does not include $M$. currentium, whose occurrence in Minas Gerais was relaying on specimens here assigned as $M$. molossus. Because the occurrence of $M$. currentium in Brazil was also based on the record of Tavares et al. (2010) (see Nogueira et al. 2014a), the number of Brazilian bats species can be updated to 177 .

The presence of endemic taxa at the limestone outcrop of Fazenda Serra Azul confirms the importance of karstic areas to the bat fauna (Trajano 1995, Tavares et al. 2010). Micronycteris sanborni and $X$. vieirai were exclusively sampled at this site, as were other more widespread species, like $P$. macrotis, $P$. kappleri, C. auritus, and Uroderma magnirostrum. Additionaly, almost $50 \%$ of the bat species reported here was found at this site, where abundant roosts and core plants in the diet of stenodermatines (e. g. Ficus and Cecropia) are available (Nogueira et al. 2003). Since we conducted our last field activities in Jaíba, in 1995, extensive changes have been promoted in the landscape of this region, largely due to the continuity of the conversion of forests into agricultural plots. Of major importance to bat conservation, however, was the creation of conservation units in karstic areas. The Fazenda Serra Azul is now part of the buffer zone of the Reserva Biológica Serra Azul (3,840 ha), integrating a new system of conservation units (Sistema de Áreas Protegidas do Jaíba). Our finding of an exotic species (Rattus rattus) at the Reserva Biológica de Jaíba is also relevant from a conservation point of view. Although only a single specimen was recorded, and its occurrence may be merely incidental, this rodent has been widely cited as a threat to natural environments (Pimentel et al. 2000, Caut et al. 2008), justifying attention in further studies in the area.

Although rarefaction curves presented here for captures in live traps and mist nets suggest that most small mammals sampled by these methods were already recorded, additional surveys are still required, particularly in conservation areas. Our list of bats from families other than Phyllostomidae, for example, is clearly incomplete (e.g. only two vespertilionids included), and additional sampling effort through active roost search and acoustic monitoring may help to fill this gap. The advantages of these complementary sampling techniques have been well demonstrated in bat surveys (e.g. Simmons \& Voss 1998, Jung \& Kalko 2011). Implementation of ecological studies on endemic/data deficient species, like $X$. vieirai, is another prominent measure that may help in future conservation plans for this important region of the Caatinga biome.

\section{Acknowledgments}

We are thankful to Fernando M. Costa, Ueldo dos Santos, and Carolina P. H. Rocha for fieldwork assistance; to Marli P. M. Lima for the identification of the Calliandra sp.; to Daniela Dias for help in the identification of Myotis lavali; to Ricardo Moratelli for sharing unpublished information on the taxonomy of Myotis and Lonchophylla; to Leandro R. Monteiro and two anonymous reviewers for comments and corrections that greatly improved a previous draft of the manuscript; to Estação Agroclimática de Mocambinho - 83389, EPAMIG/FEMO, for meteorological data; and to CNPq for financial support to MRN (Programa Nacional de Pós-doutorado - CNPq/Capes/Finep, process 151559/2008-2), ALP (process 303622/2009-1), LMP (process 305564/2010-2), and JAO (process 306935/2010-4). Field activities at the Jaíba region were partially supported by SYTEC 3 Engenharia e Controle de Corrosão LTDA.

\section{References}

ANDRADE-LIMA, D. 1981. The Caatingas Dominium. Rev. Bras. Bot. 4:149-163.

ASTÚA, D. \& GUERRA, D.Q. 2008. Caatinga bats from Mammal Collection of the Universidade Federal de Pernambuco. Chiropt. Neotrop. 14:326-338.

CARVALHO, W.D., MARTINS, M., DIAS, D. \& ESBÉRARD, C.E.L. 2013. Extension of geographic range, notes on taxonomy and roosting of Histiotus montanus (Chiroptera: Vespertilionidae) in Southeastern Brazil. Mammalia 77(3):341-346. doi: http://dx.doi.org/ 10.1515/mammalia-2012-0012

CAUT, S., ANGULO, E. \& COURCHAMP, F. 2008. Dietary shift of an invasive predator: rats, seabirds and sea turtles. J. Appl. Ecol. 45(2):428-437. doi: http://dx.doi.org/10.1111/jpe.2008.45.issue-2

CORREA, M.M.O \& PESSÔA, L.M. 1996. O cariótipo de Rhipidomys sp. (Rodentia: Cricetidae) do norte de Minas Gerais. In Resumos do XXI Congresso Brasileiro de Zoologia, 5-9 de fevereiro de 1996. Sociedade Brasileira de Zoologia, Porto Alegre, p.226.

COSTA, C.M.R., HERRMANN, G., MARTINS, C.S., LINS, L.V. \& LAMAS, I.R. (Orgs). 1998. Biodiversidade em Minas Gerais: um atlas para sua conservação. Fundação Biodiversitas, Belo Horizonte.

DITCHFIELD, A.D. \& GREGORIN, R. 2008. Xeronycteris vieirai. In IUCN 2012. IUCN Red List of Threatened Species. Version 2012.2. Electronic Database accessible at $<w w w$.iucnredlist.org $>$. Captured on 22 February 2013.

FALCÃO, L.A.D., ESPÍRITO-SANTO, M.M., LEITE, L.O., GARRO, R.N.S.L., AVILA-CABADILLA, L.D. \& STONER, K. E. 2014. Spatiotemporal variation in phyllostomid bat assemblages over a successional gradient in a tropical dry forest in southeastern Brazil. J. Trop. Ecol. 30(2):123-132. doi: http://dx.doi.org/10.1017/ S0266467413000862

FERNANDES, A. \& BEZERRA, P. 1990. Estudo Fitogeográfico do Brasil. Stylus Comunicações, Fortaleza.

FORD, C.E. \& HAMERTON, J.L. 1956. A colchicine hypotonic citrate squash sequences for mammalian chromosomes. Stain Technol. 31:247-251.

GARDNER, A.L. (ed.). 2008 [2007]. Mammals of South America, Volume 1, marsupials, xenarthrans, shrews, and bats. The University of Chicago Press, Chicago [Dated 2007; published 31 March 2008.] 
GONÇALVES, P.R., ALMEIDA, F.C. \& BONVICINO, C.R. 2005. A new species of Wiedomys (Rodentia: Sigmodontinae) from Brazilian Cerrado. Mamm. Biol. 70:46-60.

GONÇALVES, P.R., TETA, P. \& BONVICINO, C.R. 2015. Genus Holochilus, Brandt, 1835. In Mammals of South America, Volume 2, Rodents (Patton J.L., Pardiñas U.F.J. \& D’Elía G., eds).University of Chicago Press, Chicago: p.325-334.

GREGORIN, R. \& DITCHFIELD, A.D. 2005. A new genus and species of Lonchophyllini nectar-feeding bat (Phyllostomidae: Glossophaginae) from Northeastern Brazil. J. Mammal. 86: 403-414. doi: http://dx.doi.org/10.1644/BRB-229.1

GREGORIN, R. \& LOUREIRO, L.O. 2011. New records of bats for the state of Minas Gerais, with range extension of Eptesicus chiriquinus Thomas (Chiroptera: Vespertilionidae) to southeastern Brazil. Mammalia 75:291-294. doi: http://dx.doi.org/10.1515/mamm.2011.027

GREGORIN, R., GONÇALVES, E., AIRES, C.C. \& CARMIGNOTTO, A.P. 2011a. Morcegos (Mammalia: Chiroptera) da Estação Ecológica Serra Geral do Tocantins: composição específica e considerações taxonômicas. Biota Neotrop. 11(1):299-312 $\mathrm{http}: / / \mathrm{www}$.biotaneotropica.org.br/v11n1/en/abstract?article + bn03811012011 (last access in 05/11/2013). doi: http://dx.doi.org/ 10.1590/S1676-06032011000100028

GREGORIN, R., TAHARA, A.S. \& BUZZATO, D.F. $2011 \mathrm{~b}$. Molossus aztecus and other small Molossus (Chiroptera: Molossidae) in Brazil. Acta Chiropterol. 13(2):311-317. doi: http://dx.doi. org/10.3161/150811011X624794

GREGORIN, R., VASCONCELlOS, K.L. \& GIL, B.B. 2015. Two new range records of bats (Chiroptera: Phyllostomidae) for Atlantic Forest, eastern Brazil. Mammalia. 79(1):121-124. doi: http://dx.doi.org/10.1515/mammalia-2013-0142

HAMMER, O., HARPER, D.A.T. \& RYAN, P.D. 2001. PAST: Paleontological Statistics software package for education and data analysis. Paleontologia Eletronica 4(1):1-9.

HERSHKOVITZ, P. 1987. A history of the recent mammalogy of the Neotropical region from 1492 to 1850. Fieldiana, Zool. 39:11-98.

HOOD, C. \& GARDNER, A.L. 2008 [2007]. Family Emballonuridae Gervais, 1856. In Mammals of South America, Volume 1, marsupials, xenarthrans, shrews, and bats (Gardner A.L., ed.). University of Chicago Press, Chicago, p.188-207. [Dated 2007; published 31 March 2008.]

JUNG, K. \& KALKO, E.K.V. 2011. Adaptability and vulnerability of high flying Neotropical aerial insectivorous bats to urbanization. Divers. Distrib. 17:262-274. doi: http://dx.doi.org/10.1111/ddi.2011.17.issue-2

LEITE, Y. L R. 2003. Evolution and systematics of the Atlantic tree rats, genus Phyllomys (Rodentia, echimyidae), with description of two new species. Univ. Calif. Publ. Zool., 132:1-118.

LIM, B.K., ENGSTROM, M.D., REID, F., SIMMONS, N.B., VOSS, R.S. \& FLECK, D.W. 2010. A new species of Peropteryx (Chiroptera, Emballonuridae) from western Amazonia with comments on phylogenetic relationships within the genus. Am. Mus. Novit. 3686:1-20. doi: http://dx.doi.org/10.1206/691.1

LÓPEZ-BAUCELLS, A., ROCHA, R., GARCÍA-MAYES-, I., VULINEC, K. \& MEYER, C.F.J. 2013. First record of Micronycteris sanborni (Chiroptera: Phyllostomidae) from Central Amazonia, Brazil: range expansion and description of its echolocation. Mammalia 78(1):127-132.

LORINI, M.L., OLIVEIRA, J.A. \& PERSSON, V.G. 1994. Annual age structure and reproductive patterns in Marmosa incana (Lund, 1841) (Didelphidae, Marsupialia). Z. Saugetierkd. 59(2):65-73.

MAGALHÃES, G.M. \& FERREIRA, M.B. 1976. Vegetação. In Levantamento de reconhecimento com detalhes dos solos do distrito agro-industrial de Jaíba - Minas Gerais (Panoso, L.A., Santana, D.P., Souza, C.C., Sans, L.M.A., Avelar, B.C. \& Pacheco, E.B., orgs). Boletim Técnico n.54. Empresa de Pesquisa Agropecuária de Minas Gerais, Belo Horizonte, p.28-42.

MAGURRAN, A.E. 2011. Medindo a diversidade biológica. EDUFPR, Curitiba.

MMA. 2002. Avaliação e identificação de áreas e ações prioritárias para a conservação, utilização sustentável e repartição dos benefícios da biodiversidade nos biomas brasileiros. Ministério do Meio Ambiente, Secretaria de Biodiversidade e Florestas, Brasília.

MOOJEN, J. 1943. Captura e preparação de pequenos mamíferos para coleções de estudo. Imprensa Nacional, Rio de Janeiro.

MORATELLI, R. \& WILSON, D.E. 2013. Distribution and natural history of Myotis lavali (Chiroptera, Vespertilionidae). J. Mammal. 94(3):650-656. doi: http://dx.doi.org/10.1644/12-MAMM-A-257.1

MUSTRANGI, M.A. \& PATTON, J.L. 1997. Phylogeography and systematics of the slender mouse opossum Marmosops (Marsupialia, Didelphide). Univ. Calif. Publ. Zool. 130:1-86.

NIMER, E. 1989. Climatologia do Brasil. 2 ed. IBGE, Rio de Janeiro. NOGUEIRA, M.R. \& POL, A. 1998. Observações sobre os hábitos de Rhynchonycteris naso (Wied-Neuwied, 1820) e Noctilio albiventris Desmarest, 1818 (Mammalia, Chiroptera). Rev. Bras. Biol. 58(3):473-480. doi: http://dx.doi.org/10.1590/S0034-710819980003 00012

NOGUEIRA, M.R., TAVARES, V.C. \& PERACCHI, A.L. 2003. New records of Uroderma magnirostrum Davis (Mammalia, Chiroptera) from southeastern Brazil, with comments on its natural history. Rev. Bras. Zool. 20(4):691-697. doi: http://dx.doi.org/ 10.1590/S0101-81752003000400023

NOGUEIRA, M.R., POL, A., MONTEIRO, L.R. \& PERACCHI, A. L. 2008. First record of Miller's mastiff bat, Molossus pretiosus (Mammalia: Chiroptera), from the Brazilian Caatinga. Chiropt. Neotrop. 14(1):346-353.

NOGUEIRA, M.R., LIMA, I.P., MORATELLI, R., TAVARES, V. C., GREGORIN, R. \& PERACCHI, A.L. 2014a. Checklist of Brazilian bats, with comments on original records. Check List. 10 (4):808-821. doi: http://dx.doi.org/10.15560/10.4.808

NOGUEIRA, M.R., GREGORIN, R. \& PERACCHI, A.L. 2014b. Emended diagnosis of Xeronycteris vieirai (Mammalia, Chiroptera), with the first record of polyodontia for the genus. Zoologia 31:175-180.

OLIVEIRA, J.A., LORINI, M.L. \& PERSSON, V.G. 1992. Pelage variation in Marmosa incana (Didelphidae, Marsupialia), with notes on taxonomy. Z. Saugetierkd. 57:129-136.

OLIVEIRA, J.A., GONÇALVES, P.R. \& BONVICINO, C.R. 2003. Mamíferos da Caatinga. In Ecologia e conservação da caatinga (Leal, I.R., Silva, J.M.C. \& Tabarelli, M., eds). Ed. Universitária da UFPE, Recife, p.275-334.

PAGLIA, A.P., FONSECA, G.A.B da, RYLANDS, A.B., HERRMANN, G., AGUIAR, L.M.S., CHIARELLO, A.G., LEITE, Y. L.R., COSTA, L.P., SICILIANO, S., KIERULFF, M.C.M., MENDES, S.L., TAVARES, V.C., MITTERMEIER, R.A. \& PATTON J L. 2012. Lista Anotada dos Mamíferos do Brasil. 2 ed. Occasional Papers in Conservation Biology, no. 6. Conservation International, Arlington.

PANOSO, L.A., SANTANA, D.P., SOUZA, C.C. de, SANS, L.M.A., AVELAR, B.C. \& PACHECO, E.B. (Orgs). 1976. Levantamento de reconhecimento com detalhes dos solos do distrito agro-industrial de Jaíba - Minas Gerais. Boletim Técnico n. 54. Empresa de Pesquisa Agropecuária de Minas Gerais, Belo Horizonte.

PATTON, J.L., PARDIÑAS, U.F.J. \& D'ELIA, G. (Eds). 2015. Mammals of South America, Volume 2, Rodents. Chicago University Press, Chicago.

PESSÔA, L.M., CORRÊA, M.M.O., OLIVEIRA, J.A. \& LOPES, M. O.G. 2004. Karyological and morphometric variation in the genus Thrichomys (Rodentia: Echimyidae). Mamm. Biol. 69:1-12.

PESSÔA, L.M., KASAHARA, S., BRANDT, R.S. \& CORREAA, M. M.O. 1994. O cariótipo de Oryzomys subflavus (Rodentia, Cricetidae) do norte de Minas Gerais. In Resumos do XX Congresso Brasileiro de Zoologia, 24-29 de julho de 1994. Universidade Federal do Rio de Janeiro, Rio de Janeiro, p.18.

PIMENTEL, D., LACH, L., ZUNIGA, R. \& MORRISON, D. 2000. Environmental and Economic Costs of Nonindigenous Species in the United States. Bioscience 50(1):53-65. doi: http://dx.doi.org/ 10.1641/0006-3568(2000)050[0053:EAECON]2.3.CO;2

RIZZINI, C.T. 1997. Tratado de Fitogeografia do Brasil. 2 ed. Âmbito Cultural Edições, Rio de Janeiro. 
Nogueira, M. R. et al.

RODRIGUES, L. 2001. Potencial da agricultura irrigada como indutora do desenvolvimento regional: o caso do projeto Jaíba no Norte de Minas Gerais. Rev. Econ. Nordeste 32(2):206-232.

SÁ-NETO, R.J. \& MARINHO-FILHO, J. 2013. Bats in fragments of xeric woodland caatinga in Brazilian semiarid. J. Arid Environ. 90:88-94. doi: http://dx.doi.org/10.1016/j.jaridenv.2012.10.007

SANTOS, C.F., NOGUEIRA, M.R., CUNHA, N., CARVALHO, L. F. \& FISCHER, E. 2010. Southernmost record of the Sanborn's big-eared bat, Micronycteris sanborni (Chiroptera, Phyllostomidae). Mammalia 74:457-460.

SIMMONS, N.B. 1996. A new species of Micronycteris (Chiroptera: Phyllostomidae) from northeastern Brazil, with comments on phylogenetic relationships. Am. Mus. Novit. 3158:1-35.

SIMMONS, N.B. \& VOSS, R.S. 1998. The mammals of Paracou, French Guiana: a Neotropical lowland rainforest fauna, Part 1. Bats. Bull. Am. Mus. Nat. Hist. 237:1-219.

SPIX, J.B. \& MARTIUS, C.F.P. 1828. Reise in Brasilien auf Befehl Sr. Majestät Maximilian Joseph I. Königs von Baiern in den Jahren 1817 bis 1820 gemacht und beschrieben. M. Lindauer, München.

TADDEI, V.A., NOBILE, C.A. \& MORIELLE-VERSUTE, E. 1998. Distribuição geográfica e análise morfométrica comparativa em Artibeus obscurus (Schinz, 1821) e Artibeus fimbriatus Gray, 1838 (Mammalia, Chiroptera, Phyllotomidae). Ens. cienc. 2(2):71-128.

TAVARES, V.C., AGUIAR, L.M.S., PERINI, F.A., FALCÃO, F.C. \& GREGORIN, R. 2010. Bats of the state of Minas Gerais, southeastern Brasil. Chiropt. Neotrop. 16(1):675-705.

TRAJANO, E. 1995. Protecting caves for bats or bats for the cave? Chiropt. Neotrop. 1(2):19-22.
TRAJANO, E. \& GIMENEZ, E.A. 1998. Bat community in a cave from eastern Brazil, including a new record of Lionycteris (Phyllostomidae, Glossophaginae). Stud. Neotrop. Fauna E. 33(23):69-75. doi: http://dx.doi.org/10.1076/snfe.33.2.69.2156

VELAZCO, P.M. 2005. Morphological phylogeny of the bat genus Platyrrhinus Saussure, 1860 (Chiroptera: Phyllostomidae) with the description of four new species. Fieldiana, Zool. 105:1-54.

VELAZCO, P.M., GARDNER, A.L. \& PATTERSON, B.D. 2010. Systematic of the Platyrrhinus helleri species complex (Chiroptera, Phyllostomidae), with descriptions of two new species. Zool. J. Linn. Soc-Lond. 159:785-812.

VELAZCO, P.M., GREGORIN, R., VOSS, R.S. \& SIMMONS, N.B. 2014. Extraordinary local diversity of disk-winged bats (Thyropteridae: Thyroptera) in northeastern Peru, with the description of a new species and comments on roosting behavior. Am. Mus. Novit. 3795:1-28. doi: http://dx.doi.org/10.1206/3795.1

WILLIAMS, S.L., WILLIG, M.R. \& REID, F.A. 1995. Review of the T. bidens complex (Mammalia: Chiroptera), with descriptions of two new subspecies. J. Mammal. 76:612-626. doi: http://dx.doi.org/ $10.2307 / 1382370$

WILLIAMS, S.L. \& GENOWAYS, H.H. 2008 [2007]. Subfamily Phyllostominae Gray, 1825. In Mammals of South America, Volume 1, marsupials, xenarthrans, shrews, and bats (Gardner, A.L., ed.). University of Chicago Press, Chicago, p.255-300. [Dated 2007; published 31 March 2008.]

WILSON, D.E. \& REEDER, D.M. (eds). 2005. Mammal species of the world: a taxonomic and geographic reference. 3 ed. Johns Hopkins University Press, Baltimore. 